\title{
Laboratory and Commercial Synthesized Zinc Oxide Nanoparticles Adsorption onto Coconut Husk: Characterization, Isotherm, Kinetic, and Thermodynamic Studies
}

\author{
Eric Kwabena Droepenu ${ }^{1,2, * \mathbb{D}}$, Ebenezer Aquisman Asare ${ }^{1,2} \mathbb{D}$, Samuel Boakye Dampare ${ }^{2} \mathbb{D}$, Dennis \\ Kpakpo Adotey ${ }^{2}$, Alexander Obiri Gyampoh ${ }^{3}$, Eugene Kumi-Arhin ${ }^{4}$ \\ 1 Resource Chemistry Program, Faculty of Resource Science and Technology, Universiti Malaysia Sarawak 94300, Kota \\ Samarahan, Sarawak, Malaysia \\ 2 Graduate School of Nuclear and Allied Sciences, University of Ghana, AE1, Kwabenya-Accra, Ghana \\ 3 Departments of Science, Kibi Presbyterian College of Education, Kibi, Eastern Region, Ghana \\ 4 Department of Chemistry, School of Physical Science, College of Agriculture and Natural Sciences, University of Cape \\ Coast, Cape Coast, Ghana \\ * Correspondence: kobladodzie01@yahoo.com;
}

Received: 2.06.2020; Revised: 29.06.2020; Accepted: 30.06.2020; Published: 5.07.2020

\begin{abstract}
The accelerating application of zinc oxide nanoparticles ( $\mathrm{ZnO}-\mathrm{NPs}$ ) has called for attention to their potential environmental and human health risks. This work aimed to investigate the sorption efficiency of laboratory and commercial synthesized nanocrystalline zinc oxide onto raw coconut husk in a batch adsorption study. Characterization of samples was performed by employing spectroscopies techniques such as X-ray Diffraction Spectroscopy, Field Emission Scanning Electron Microscopy, Transmission Electron Spectroscopy, Fourier transform IR Spectroscopy, and Brunauer-EmmettTeller. A spherical shaped nanocrystalline $\mathrm{ZnO}$ with a mean crystallite and particle size of $14.7 \mathrm{~nm}$ and $24 \mathrm{~nm}$ by XRD and TEM was synthesized as compared to the commercial ZnO-NPs of size $<50 \mathrm{~nm}$. The maximum percentage removal of $88 \%(0.13 \mathrm{mg} / \mathrm{g})$ and $90 \%(0.16 \mathrm{mg} / \mathrm{g})$ for laboratory synthesized and commercial $\mathrm{ZnO}-\mathrm{NPs}$ respectively was recorded at an optimum contact time of 80 minutes. The data also indicated $2.0 \mathrm{~g}$ sorbent mass and $\mathrm{pH}$ of 8 as the optimum conditions for maximum percentage removal of these nanoparticles. Both Langmuir and Freundlich models fitted best for laboratory synthesized $\mathrm{ZnO}-\mathrm{NPs}$ with a maximum capacity of $0.797 \mathrm{mg} / \mathrm{g}$, whereas Langmuir isotherm model alone with a maximum capacity of $0.710 \mathrm{mg} / \mathrm{g}$ fitted well for commercial $\mathrm{ZnO}-\mathrm{NPs}$. The $\mathrm{n}$-value from the Freundlich model, as well as separation factor $\left(\mathrm{R}_{\mathrm{L}}\right)$ were greater than unity suggesting a favorable adsorption process. The study obeyed pseudo-second-order, which was exothermic with a high degree of freedom of sorbent-sorbate interaction. The results suggested that coconut husk is potentially scalable for removing $\mathrm{ZnO}-\mathrm{NPs}$ from wastewater.
\end{abstract}

Keywords: Zinc oxide nanoparticles; Adsorption studies; Raw coconut husk; Thermodynamic studies; Kinetic studies; Isotherm model.

(C) 2020 by the authors. This article is an open-access article distributed under the terms and conditions of the Creative Commons Attribution (CC BY) license (https://creativecommons.org/licenses/by/4.0/).

\section{Introduction}

In recent years, nanotechnology has seen significant growth of engineered nanomaterials $\left(\mathrm{ZnO}, \mathrm{TiO}_{2}, \mathrm{Ag}, \mathrm{CeO}_{2}, \mathrm{SiO}_{2}\right)$ in its production [1]. These materials find their application in consumer products, food packaging, and food additives, pharmaceuticals, optical 
and electrical devices, photodetectors, photocatalysts, an antifouling pigment in paints, and adsorbents for environmental remediation [2-8]. Through various simulated experiments, it was predicted that the emission concentration of $\mathrm{Ti}, \mathrm{Ag}$, and $\mathrm{Zn}$ nanoparticles in the environment were in the ranges of $10^{-8}-10,10^{-8}-10^{-1}$, and $10^{-3}-10^{0}$, respectively [9].

Owing to zinc oxide nanoparticles (ZnO-NPs) wide bandgap of $3.37 \mathrm{eV}$ at room temperature and the different morphologies they exhibit, they tend to be used in sunscreens and photocatalysts, due to their excellent absorption of UV radiation [10], antibacterial, anticancer, and antiviral agents due to the different structures they exhibit [11-19]. Despite the importance of these materials in their industrial applications, their potential risk to the environment and public health is another concern when they exceed their threshold concentrations [20-21]. The maximum permissible limit of zinc in drinking water is $2.0 \mathrm{mg} / \mathrm{l}$, as suggested by the Malaysian Environmental Quality Act, 1974.

However, various biological and chemical treatment techniques have been conducted on the removal of these metal ions and nano-sized particles such as chemical precipitation, ionexchange, reverse osmosis, electroflotation, ultrafiltration, or electrochemical deposition [2223]. Although these methods contributed tremendously in alleviating these pollutants from water, they are saddled with drawbacks or limitations. Some of these limitations include economic feasibility, less effective treatment of pollutants at lower concentrations, and the creation of a large amount of sludge after the process [24-27]. Meanwhile, adsorption has been universally accepted and demonstrated to be a favorable and feasible alternative for effective pollutant removal from wastewater and water [28]. This is due to its simplicity of design, flexibility in operation, and non-sensitivity to toxic substances due to the nature of the adsorbent used [29]. Industries quest for low-cost operations in water remediation has led to numerous studies to identify low cost and highly efficient sorbents derived from renewable lignocellulose biomass from agricultural by-products such as Pistachio Shell [30], Rubber Seed Shell [31], Moroccan attapulgite [32], Adulsa (Justicia adhatoda) Leaves powder [33], willow, paulownia, wheat straw and maize stalks [34], Canna generalis [35], coconut shell, Eucheuma spinosum, and walnut shell [36-38]. Lignocellulose biomass is known for its economic and environmentally friendly nature, its availability, renewability, and cost-effectiveness [39], which can be used in the raw state, carbonized, or chemically treated state [40-42] to enhance their removal efficiency towards pollutants as indicated by [40]. The high content of cellulose, lignin, and other polar functional groups of lignin such as alcohols, aldehydes, ketones, carboxylic, phenolic, and ether groups in lignocellulose biomass enhance the adsorbent binding ability of pollutants through different binding systems [43].

It is against this backdrop that dry raw coconut husk $(\mathrm{RCH})$ as sorbent material was used in a batch adsorption studies to determine the removal efficiency of two ZnO-NPs. One of the $\mathrm{ZnO}-\mathrm{NPs}$ was synthesized through a solvothermal technique and characterized ( $\mathrm{L}-\mathrm{ZnO}-$ NPs), whereas the other is a commercial ZnO-NPs purchased from suppliers (C-ZnO-NPs). Characterization of sorbents and sorbate, adsorption kinetics using pseudo-first, pseudo-second and intra-particle diffusion models, adsorption isotherm using Langmuir, Freundlich, and Temkin models as well as thermodynamics parameters were examined to identify the sorption mechanism of the two nanoparticles onto the sorbents. This study was carried out in Kota Samarahan in the Sarawak state of Malaysia from August 2019 to January 2020. 


\section{Materials and Methods}

\subsection{Materials.}

Chemicals employed in this work are of analytical reagent grade supplied by Sigma Aldrich, India, and VWR Amresco, US. The chemicals include Zinc chloride $\left(\mathrm{ZnCl}_{2}\right)$, Nitric acid $\left(\mathrm{HNO}_{3}\right)$, absolute ethanol, and sodium hydroxide $(\mathrm{NaOH})$. All solutions used throughout the study were prepared using deionized water (DW).

\subsection{Sorbent collection and preparation.}

The coconut fruits (Fig. 1) were purchased from the Bandariyyah market, Kota Samarahan, in the Sarawak state of Malaysia. The dry husks obtained from dehusking the fruit were cleaned with tap water followed by air-dried for one week, and then oven-dried at a temperature of $80{ }^{\circ} \mathrm{C}$ for 6 hours to obtain dry biomass. The dry biomass was ground to a fine powder using a blender (FGR-350) and screened through Retsch Analysensieb sieve mesh of size $210 \mu \mathrm{m}$ (DIN-ISO 3310/1) on a mechanical shaker (Endecotts EFL 2 mk3 Test Sieve Shaker). The sieved sample ( $\mathrm{RCH})$ was stored in zip-lock plastic bags to avoid moisture and fungal infection. Some physicochemical determinations were carried out on RCH sample, which is illustrated in Table 1.

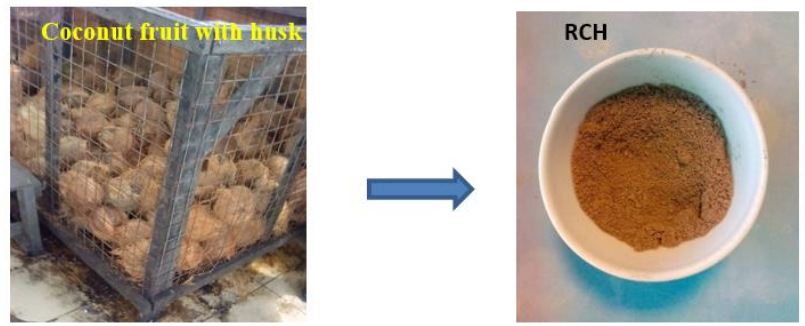

Figure 1. Coconut fruit dehusked and processed into powdered raw coconut husk sorbent (RCH).

\subsection{Laboratory synthesis of $\mathrm{ZnO}-\mathrm{NPs}$.}

The laboratory synthesis of L-ZnO-NPs sample was based on the solvothermal method reported by [44] with slight changes. An amount of $4.08 \pm 0.1 \mathrm{~g}(0.01 \mathrm{~mol})$ of $\mathrm{ZnCl}_{2}$ was dissolved in $50 \mathrm{~mL}$ of absolute ethanol in a $250 \mathrm{~mL}$ Schott bottle and heated to a temperature of $60{ }^{\circ} \mathrm{C}$ with constant stirring using electrical stirring hotplate (Favorit). Subsequently, $4.00 \pm$ $0.1 \mathrm{~g}(0.01 \mathrm{~mol})$ of $\mathrm{NaOH}$ was also weighed and dissolved in $50 \mathrm{ml}$ of absolute ethanol in 250 $\mathrm{ml}$ Schott bottle under the same condition as the Zinc precursor. The $\mathrm{NaOH}$ solution was slowly drained dropwise from a burette into the $\mathrm{ZnCl}_{2}$ solution, maintaining the temperature at $60{ }^{\circ} \mathrm{C}$ with vigorous stirring for 60 minutes until a white precipitate was formed. The mixture was cooled at room temperature for 180 minutes before centrifuging with FLETA 5 Multi-Purpose Centrifuge at $4000 \mathrm{rpm}$ for 30 minutes. The precipitate was filtered using $0.45 \mu \mathrm{m}$ Whatman filter membrane, washed twice with acetone and then with deionized water, dried at room temperature, and finally ground in a powdery form for characterization.

\subsection{Sorbate preparation.}

Stock solutions of both L-ZnO-NPs and C-ZnO-NPs were prepared by dissolving 1.00 $\pm 0.1 \mathrm{~g}$ each of the nanocrystalline powder of each sample in $10.0 \mathrm{ml}$ of concentrated $\mathrm{HNO}_{3}$ acid, sonicated using Ney ULTRAsonik (15 min; $20 \mathrm{KHz} ; 200 \mathrm{~W} / \mathrm{L}$ ) and a solution made up to $1000 \mathrm{mg} / \mathrm{l}$ using DW. Serial dilutions of $0.2-2.0 \mathrm{mg} / \mathrm{l}$ were prepared from the stock solution 
and analyzed spectroscopically using Atomic Absorption Spectrometer (iCE 3000 Series AA, Thermo Scientific). Conductivity and $\mathrm{pH}$ of the solution were also determined by EUTECH COND $6^{+}$and PHS-W Series Benchtop $\mathrm{pH} / \mathrm{mV}$ Meter, respectively.

\subsection{Characterization of sorbent and sorbate.}

$\mathrm{RCH}$ and $\mathrm{L}-\mathrm{ZnO}-\mathrm{NPs}$ Infrared spectra were obtained in $\mathrm{KBr}$ disks from $400-4000 \mathrm{~cm}^{-1}$ using Thermo Nicolet iS10 Fourier transform IR spectrometer. The specific surface areas were determined from the adsorption-desorption nitrogen isotherms using a Quantachrome, US Autosorb iQ, version 2.01 apparatus. Samples were degassed at $175{ }^{\circ} \mathrm{C}$ for 120 minutes prior to the analysis [45] in flowing $\mathrm{N}_{2}$ gas. The surface area was computed by applying the Brunauer-Emmett-Teller (BET) technique from the linear part of the nitrogen adsorption isotherm. Morphology of the RCH and L-ZnO-NPs were evaluated using Field Emission Scanning Electron Microscopy, FESEM (Carl Zeiss GeminiSEM 500) with an acceleration voltage of $10.0 \mathrm{kV}$, with a chamber pressure of $40 \mathrm{~Pa}$ and a working distance of $11.6 \mathrm{~mm}$. Also, Transmission Electron Microscopy analysis, TEM was carried out using TEM (JEOL 1230, Japan) with the sample loaded onto a Foamvar film Copper grid (FF300-Cu) before being observed. The elemental components of the samples were analyzed with Energydispersive X-ray Spectroscopy, EDX (JEOL 6390LA, Japan). L-ZnO-NPs were further characterized using X-ray Diffraction, XRD, (Panalytical X'Pert Pro MPD PW3040/60) for its crystal structure and crystallite size. Diffraction patterns from the XRD analysis in Figure 3 were obtained using X-ray diffractometer with $\mathrm{Cu}-\mathrm{K} \alpha$ radiation of $40 \mathrm{kV}$ and $30 \mathrm{~mA}$ with a step size of $0.017^{\circ}$. Sample preparation for FE-SEM, EDX, and FT-IR were carried out using the method outlined by [46-47].

\subsection{Batch adsorption study.}

ZnO-NPs sorption from solution onto $\mathrm{RCH}$ was examined in a batch mode as a function of the sorbent mass, contact time, $\mathrm{pH}$, initial sorbate concentration, and temperature. Each study utilized $50 \mathrm{ml}$ of known concentration of the sorbate solutions (L-ZnO-NPs and C-ZnONPs) with $0.5 \mathrm{~g}$ of $\mathrm{RCH}$ added in a $250 \mathrm{ml}$ covered Erlenmeyer flask at $30 \pm 0.5^{\circ} \mathrm{C}$, and the mixture stirred on an electric hotplate magnetic stirrer (Fisherbrand) at $150 \mathrm{~min}^{-1}$ at a speed of $450 \mathrm{rpm}$. Aliquots of the samples were taken during stirring at preset time intervals and filtered using $0.45 \mu \mathrm{m}$ filter paper and analyzed spectroscopically using AAS. All experiments were conducted in duplicates and two controls (adsorbent + DW; and DW only) in order to estimate the amount of any $\mathrm{Zn}$ that might be present in the sorbent. The initial sorbate concentration in the test solution and the adsorbent dosage was varied to investigate their effect on the sorption kinetics. The $\mathrm{pH}$ impact was investigated over a $\mathrm{pH}$ range of 2-13, where adjustments were made using $\mathrm{NaOH}$ or $\mathrm{HCl}$ solution and a $\mathrm{pH}$ meter. The study also varied the temperature in a range of 298-343 K to determine the effect of the thermodynamic parameters. The quantity of sorption at time $\mathrm{t}$, qt (mg/g), was computed by employing the equation:

$$
\begin{aligned}
& \text { Removal }(\%)=\left(C_{o}-C_{e}\right) / C_{o} \times 100 \\
& q_{e}=\left(C_{o}-C_{e}\right) \cdot \mathrm{V} / \mathrm{W}
\end{aligned}
$$

Where, $C_{o}$ and $C_{e}(\mathrm{mg} / \mathrm{L})$ represent the sorbate ions concentrations at initial, and equilibrium contact time, respectively, $\mathrm{V}$ represents the solution volume $(\mathrm{L})$ and $\mathrm{W}$ is the mass of adsorbent used $(\mathrm{g})$ and $\mathrm{q}_{\mathrm{e}}$ is the amount of sorbate adsorbed at equilibrium $(\mathrm{mg} / \mathrm{g})$. 


\subsection{Kinetic study.}

Sorption kinetics of both L-ZnO-NPs and C-ZnO-NPs onto $\mathrm{RCH}$ were determined using pseudo-first-order, pseudo-second-order, and intra-particle diffusion models were used. The equations for pseudo-first-order (Equ. 3), pseudo-second-order (Equ. 4) and intra-particle diffusion (Equ. 5) models are represented as follows;

$$
\log \left(q_{e}-q_{t}\right)=\log q_{e}-k_{1} t / 2.303
$$

Where; $\mathrm{k}_{1}\left(\mathrm{~min}^{-1}\right)$ - rate constant of the pseudo-first-order sorption, $\mathrm{q}_{\mathrm{t}}(\mathrm{mg} / \mathrm{g})$ - the amount of $\mathrm{ZnO}-\mathrm{NPs}$ adsorbed by sorbent at time $\mathrm{t}(\mathrm{min})$ and $\mathrm{q}_{\mathrm{e}}(\mathrm{mg} / \mathrm{g})$ - the amount of $\mathrm{ZnO}-\mathrm{NPs}$ adsorbed at equilibrium. The fairly linear plots of $\log \left(\mathrm{q}_{\mathrm{e}}-\mathrm{q}_{\mathrm{t}}\right)$ versus $\mathrm{t}$ confirm the applicability of the above equation for $\mathrm{ZnO}-\mathrm{NPs}$ onto sorbent. The value of $\mathrm{k}_{1}$ was calculated from the slope of this linear plot.

$$
t / q_{t}=1 / k_{2} q_{e}^{2}+t / q_{e}
$$

Where; $\mathrm{k}_{2}\left(\mathrm{~g} / \mathrm{mg} \mathrm{min}^{-1}\right)$ is rate constant. $\mathrm{k}_{2}$ and $\mathrm{q}_{\mathrm{e}}$ can be obtained from the intercept and slope of plotting of $\mathrm{t} / \mathrm{q}_{\mathrm{t}}$ versus $\mathrm{t}$.

$$
q_{t}=k_{i d} \sqrt{t}+I
$$

Where, $k_{i d}$ is intra-particle diffusion rate constant $\left(\mathrm{mg} / \mathrm{g} \min ^{1 / 2}\right)$, and $\mathrm{I}$ is the thickness of the boundary layer $(\mathrm{mg} / \mathrm{g})$.

A linear relationship of Weber-Morris plot of $q_{t}$ versus $\sqrt{t}$ satisfies the sorption process to be controlled by intra-particle diffusion only. Multi-linear plots signify more than two steps influencing the sorption process.

\subsection{Equilibrium study.}

The sorption equilibrium data obtained was analyzed using three isotherm models; Langmuir, Freundlich, and Temkin isotherms. Langmuir isotherm model assumes that a finite number of active sites are distributed homogeneously over the surface of the sorbent with the same affinity for adsorption. The equation is expressed as;

$$
1 / q_{e}=\left[1 / Q_{o} K\right] 1 / C_{e}+1 / Q_{o}
$$

Where, $\mathrm{C}_{\mathrm{e}}$ - equilibrium concentration, $\mathrm{mg} / \mathrm{g}, \mathrm{q}_{\mathrm{e}}-$ amount absorbed at equilibrium, mg/g, $\mathrm{Q}_{\mathrm{o}}$, and $\mathrm{K}$ - Langmuir constants relating to adsorption capacity and energy of adsorption, which was determined from the slope and intercept of the linear plot of 1/qe Vs. 1/Ce. The essential features of a Langmuir isotherm can be expressed in terms of a dimensionless constant separation factor $\mathrm{R}_{\mathrm{L}}$ that is used to predict the favorability or non-favorability of the sorption process. The separation factor, $\mathrm{R}_{\mathrm{L}}$ is defined by the equation:

$$
R_{L}=1 / 1+K C_{o}
$$

Where, $\mathrm{C}_{\mathrm{o}}$ - sorbate concentration, $\mathrm{mg} / \mathrm{l}, \mathrm{K}$ - Langmuir adsorption equilibrium constant, $\mathrm{L} / \mathrm{g}$. The isotherm is unfavorable when $R_{L}$ is greater than 1 , the isotherm is linear when $R_{L}$ is equal to 1 , the isotherm is favorable when $\mathrm{R}_{\mathrm{L}}$ is greater than 0 but less than 1 , and the isotherm is irreversible when $\mathrm{R}_{\mathrm{L}}$ is equal to 0 .

Freundlich isotherm model assumes that, as the sorbate concentration increases, its concentration on the sorbent surface also increases, and correspondingly, the sorption energy exponentially decreases on completion of the sorption centers of the adsorbent. The equation relating to this model is:

$$
\log q_{e}=\log K_{f}+\frac{1}{n} \log C_{e}
$$


Where, $\mathrm{q}_{\mathrm{e}}$ - amount adsorbed at equilibrium, $\mathrm{mg} / \mathrm{g}, \mathrm{C}_{\mathrm{e}}$ - equilibrium concentration, $\mathrm{mg} / \mathrm{l}, \mathrm{K}_{\mathrm{f}}$, and $\mathrm{n}-$ Freundlich model constants. These constants can be obtained from the slope and intercept of the plot of $\log \mathrm{q}_{\mathrm{e}}$ against $\log \mathrm{C}_{\mathrm{e}}$.

Temkin isotherm also assumes that the fall in the heat of sorption is linear rather than logarithmic, as implied in the Freundlich equation. The isotherm model relates the equation:

$$
q_{e}=B_{T} \operatorname{In} A_{T}+B_{T} \operatorname{In} C_{e}
$$

Where, $\mathrm{B}_{\mathrm{T}}=\left(\mathrm{RT} / \mathrm{b}_{\mathrm{T}}\right), \mathrm{q}_{\mathrm{e}}-$ amounts adsorbed at the equilibrium concentration, $\mathrm{mg} / \mathrm{g}, \mathrm{C}_{\mathrm{e}}-$ amounts adsorbed at the equilibrium concentration, $\mathrm{mg} / \mathrm{l}, \mathrm{T}$ - absolute temperature, $\mathrm{K}, \mathrm{R}$ universal gas constant, $8.314 \mathrm{~J} /(\mathrm{mol} \cdot \mathrm{K})$. The constant $\mathrm{b}_{\mathrm{T}}$ is related to the heat of adsorption.

\subsection{Thermodynamic study.}

The thermodynamic concept assumes that in an isolated system, energy cannot be gained or lost, and the entropy change is the only driving force. In this study, both energy and entropy factors were considered to determine which process will occur spontaneously. Thermodynamic variables $\left(\Delta G^{o}, \Delta H^{o}\right.$ and $\left.T \Delta S^{\circ}\right)$ were determined using the equation;

$$
\begin{aligned}
& \Delta G^{o}=-R T \text { In } K_{c} \\
& K_{c}=q_{e} / C_{e} \\
& \Delta G^{o}=\Delta H^{O}-T \Delta S^{o} \\
& \operatorname{InK}_{c}=-\Delta G^{o} / R T=\Delta S^{o} / R-\Delta H^{o} / R T
\end{aligned}
$$

Where, $\mathrm{R}$ represents gas constant $\left(8.314 \mathrm{~J} \mathrm{~mol}^{-1} \mathrm{~K}^{-1}\right), \mathrm{T}$ represents temperature $(\mathrm{K}), \Delta \mathrm{G}^{\circ}$ represent Gibbs free energy change, $\Delta \mathrm{H}^{\circ}$ represent enthalpy change, $\Delta \mathrm{S}^{\circ}$ is entropy change, and $\mathrm{K}_{\mathrm{c}}$ is the distribution coefficient, $\mathrm{q}_{\mathrm{e}}$ and $\mathrm{C}_{\mathrm{e}}$ represent the equilibrium ZnO-NPs concentration on $\mathrm{RCH}(\mathrm{mg} / \mathrm{g})$ and in the solution $(\mathrm{mg} / \mathrm{l})$ respectively.

$\Delta \mathrm{H}^{\circ}$ and $\Delta \mathrm{S}^{\circ}$ are determined from the slope and intercept of a linear vant' Hoff plot of

\begin{tabular}{|c|c|c|c|}
\hline Sample & Characteristics & Value & Methodology \\
\hline \multirow[t]{7}{*}{ RCH } & Bulk density $\left(\mathrm{gcm}^{-3}\right)$ & $0.43 \pm 1.07$ & $\begin{array}{l}\text { International Science Congress Association } \\
\text { (ISCA) }\end{array}$ \\
\hline & Particle density $\left(\mathrm{gcm}^{-3}\right)$ & $0.61 \pm 1.92$ & Pycnometric method \\
\hline & Moisture content (wt.\%) & $10.05 \pm 1.25$ & ASTM 2867-99 \\
\hline & Ash content (wt.\%) & $5.85 \pm 0.18$ & ASTM D2866-94 \\
\hline & $\%$ Extractives (wt.\%) & $9.89 \pm 1.19$ & ASTM D 1105-56 \\
\hline & $\alpha$-Cellulose (wt.\%) & $44.31 \pm 0.88$ & ASTM D 1103-55T \\
\hline & Lignin (wt.\%) & $42.58 \pm 0.53$ & ASTM D 1106-56 \\
\hline \multirow{5}{*}{$\begin{array}{l}\text { C-ZnO- } \\
\text { NPs }\end{array}$} & Particle size & $<50 \mathrm{~nm}$ & \\
\hline & BET & $>97 \%$ & \\
\hline & Surface area & $>10.8 \mathrm{~m}^{2} / \mathrm{g}$ & \\
\hline & Density & $>5.61 \mathrm{~g} / \mathrm{ml}$ & \\
\hline & Dopant & $6 \% \mathrm{Al}$ & \\
\hline
\end{tabular}
In $\left(\mathrm{K}_{\mathrm{c}}\right)$ versus $1 / \mathrm{T}$.

\section{Results and Discussion}

\subsection{Physico-chemical parameters.}

Table 1. Physico-chemical characteristics of RCH and C-ZnO-NPs.

\subsection{Characterization.}

\subsubsection{XRD analysis.}

Figure 2 shows the XRD pattern of L-ZnO-NPs prepared via solvothermal technique. The peaks observed at $2 \theta$ around $31.8,34.7,36.4,47.8,56.8,63.0$ and 68.0 corresponds to the 
reflection from (010), (002), (011), (012), (110), (013), and (112) and are indexed to planes of hexagonal wurtzite structure of $\mathrm{ZnO}$ with ICSD Number (ICSD: 98000-9346) and PDF Number (Experimental and calculated powder diffraction data) of 36-1451 and 01-074-0534 respectively. The broadened patterns depict the nanosize of the $\mathrm{ZnO}$ crystals [44,48-49]. The XRD diffraction patterns of the synthesized NPs were identified as being $100 \%$ pure ZnO with the average crystallite size calculated using Scherer's formula [50];

$$
\begin{aligned}
D & =\frac{K \lambda}{\beta \cos \theta} \\
\beta & =\sqrt{\beta^{2} F W H M-\beta_{o}^{2}}
\end{aligned}
$$

Where, $\mathrm{K}$ is shape factor $=0.89, \beta(\mathrm{FWHM})$ is the full-width half maximum of the diffraction peak, and $\beta_{\mathrm{o}}$ is the correction factor for instrumental broadening $\left(0.07^{\circ} 2 \theta\right)$.

The mean crystallite size of the sample was found to be $14.7 \pm 2.3 \mathrm{~nm}$, which was similar to a study by [45] but with a flake-like morphology.

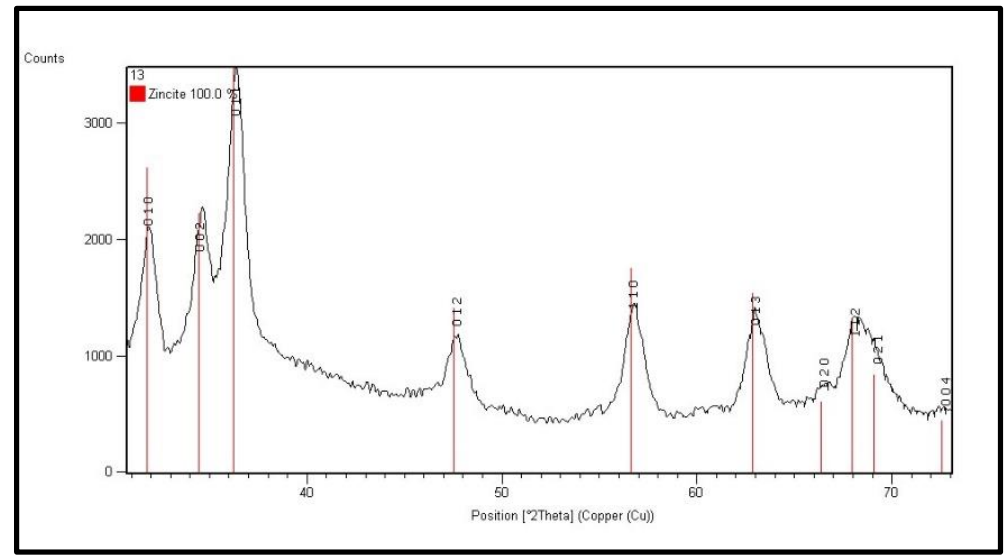

Figure 2. XRD diffractogram of $\mathrm{L}-\mathrm{ZnO}-\mathrm{NPs}$ synthesized using $\mathrm{ZnCl}_{2}$ and $\mathrm{NaOH}$.
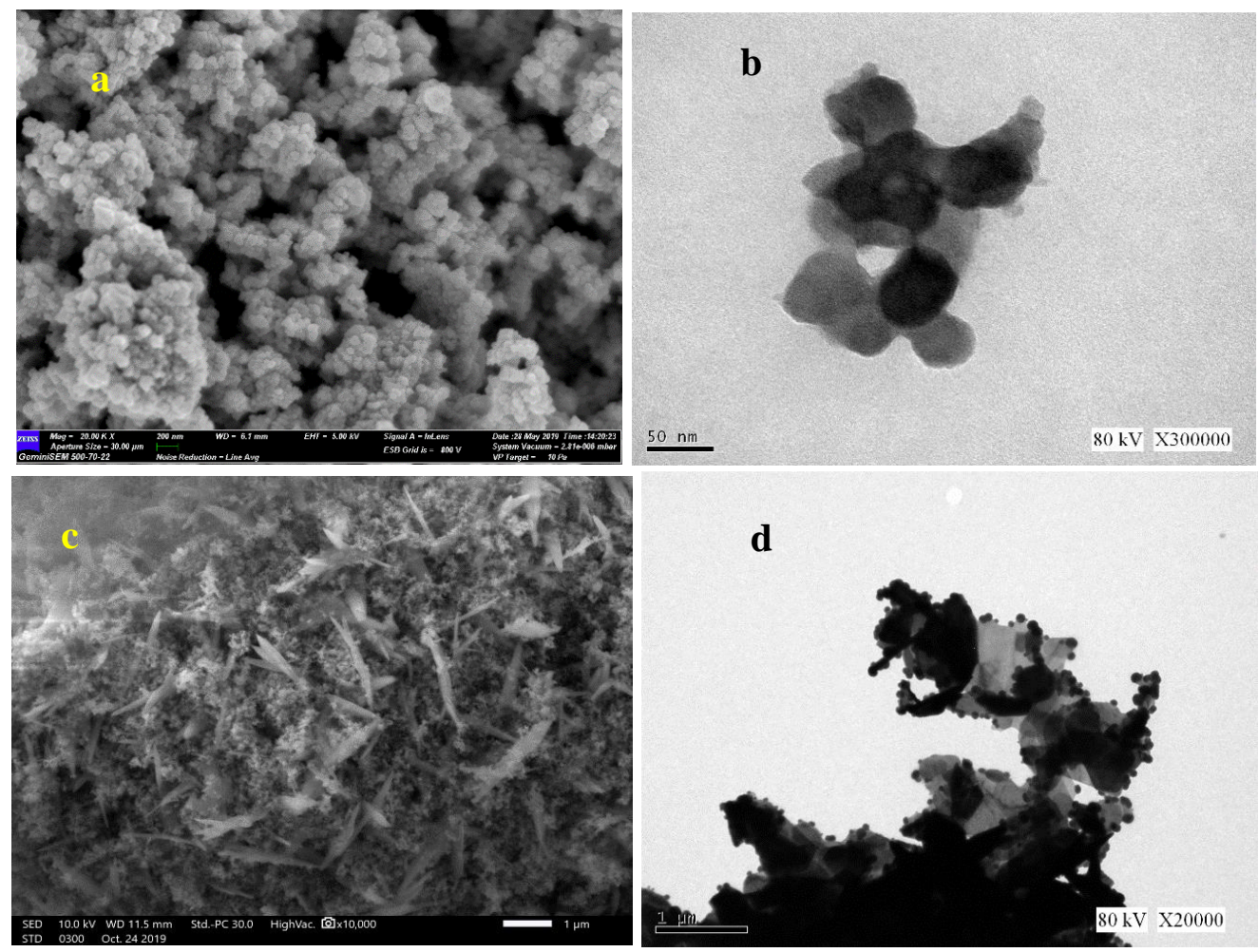

Figure 3. (a) FESEM (b) TEM images of L-ZnO-NPs (c) FESEM (d) TEM images of C-ZnO-NPs. 


\subsubsection{FESEM and TEM analysis.}

The FESEM and TEM images of L-ZnO-NPs are represented in Figure 3 ( $a \& b$ ), respectively. The morphology of the synthesized sample (L-ZnO-NPs) revealed spherical shaped structures with agglomeration/aggregation of the particles. The average particle size recorded by the FESEM and TEM is $36.0 \mathrm{~nm}$ and $24.0 \mathrm{~nm}$, respectively. Similar morphology was obtained when zinc acetate as a precursor in Triethanolamine (TEA) and Ethylene Glycol was used in a solvothermal method [51-52].

With respect to the adsorbent used for the studies, the SEM micrograph reveals significant changes in the surface morphology of the sorbent both before and after the adsorption process. The rough and heterogeneous surface nature of $\mathrm{RCH}$ before adsorption (Fig. 4a) predicts a high probability of active sites for the attachment of the sorbate ions [53]. The uptake of ZnO NPs onto RCH (Fig. 4b) reveals a change in morphology of the sorbent's surface been smooth.
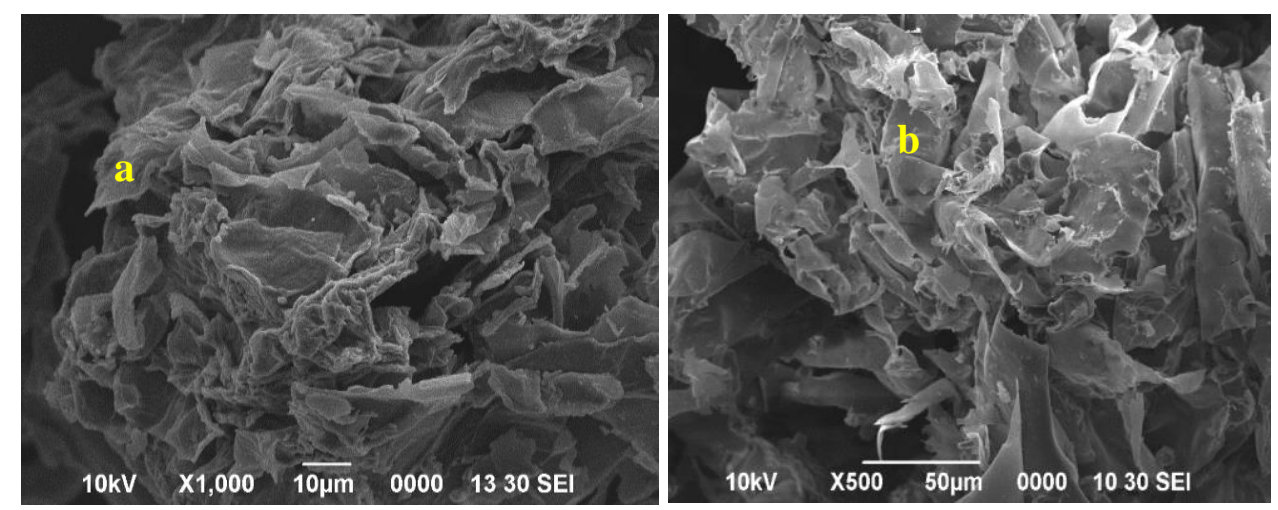

Figure 4. SEM micrograph of (a) RCH before adsorption (b) RCH after adsorption studies.

\subsubsection{BET analysis.}

The BET surface area of RCH determined from the isotherm plot, as shown in Fig 5, was found to be $2.60 \mathrm{~m}^{2} / \mathrm{g}$ with average pore size and volume of $6.53 \mathrm{e}+01 \AA$ and $8.45 \mathrm{e}-03$ $\mathrm{cm}^{3} / \mathrm{g}$, respectively. The adsorption isotherm for this sample corresponds to Type IV based on the IUPAC classification in determining the surface area of samples reported by [54]. This type reveals the presence of a mesoporous surface structure often correlated to the presence of slitshaped mesopores [55]. Though the surface area tends to be small, the multiple functional groups from the FTIR characterization of the sorbent enhanced the adsorption capacity.

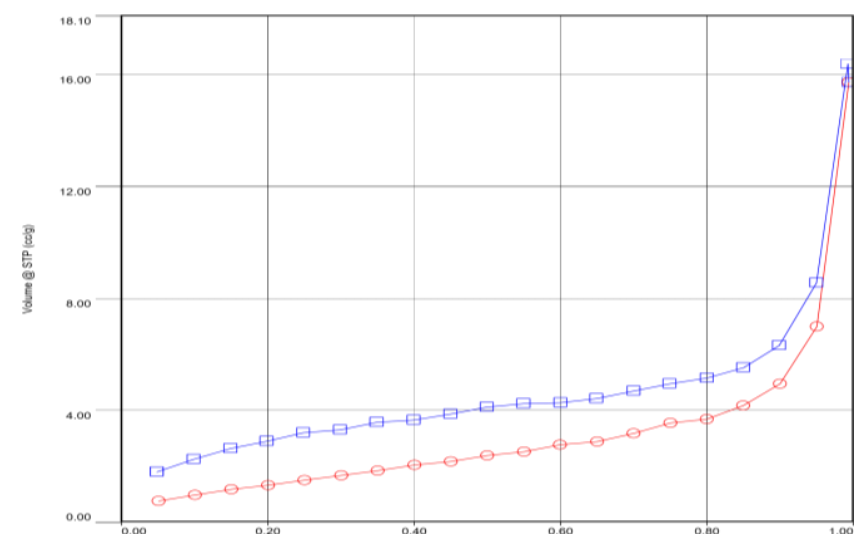

Figure 5. $\mathrm{N}_{2}$ adsorption- desorption isotherms of $\mathrm{RCH}$ sorbent. 


\subsubsection{EDX analysis.}

EDX spectra of the samples (L-ZnO-NPs and RCH) displayed in Figure 6 (a \& b) detailed the elemental compositions of each sample. From the analysis, the samples appear to be pure according to their elemental compositions.
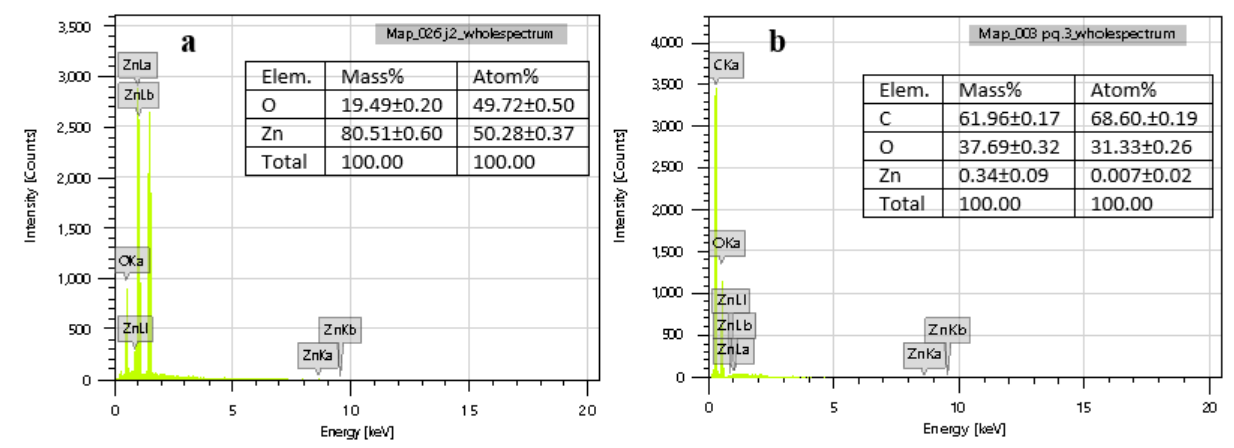

Figure 6. EDX spectra of (a) L-ZnO-NPs (b) RCH.

\subsubsection{FT-IR analysis.}

The infrared spectra of L-ZnO NPs and RCH used in this study are shown in Figure 7 (a \& b). The characteristic band of wurtzite $\mathrm{ZnO}$ in L-ZnO-NPs sample occurred at a peak height of $580.02 \mathrm{~cm}^{-1}$. This agrees with a study by [56-57] who reported the characteristic band for $\mathrm{ZnO}$ stretching mode in the range of $420-660 \mathrm{~cm}^{-1}$ when zinc nitrate hexahydrate and polyethylene glycol was used in in a $\mathrm{ZnO}$ synthesis using the microwave-assisted solvothermal technique. The characteristic broad bands observed at $3124.53 \mathrm{~cm}^{-1}$ and $\mathrm{t} 1543.40 \mathrm{~cm}^{-1}$ (in the case of L-ZnO-NPs) correspond to $\mathrm{O}-\mathrm{H}$ stretching and bending of the hydroxyl group. The intense sharp peak at $1400.97 \mathrm{~cm}^{-1}$ could be attributed to $-\mathrm{C}-\mathrm{H}$ bending in an alkane.

However, IR spectrum of RCH (Fig 7b) reveals a broad peak positioned at $3336 \mathrm{~cm}^{-1}$ to be attributed to $\mathrm{O}-\mathrm{H}$ stretching vibration due to the intermolecular hydrogen bonding of alcohols, phenols, and carboxylic acids verifying the presence of hydroxyl functional group on the sorbent surface [58].

The peak located at $2359 \mathrm{~cm}^{-1}$ could also be associated with the presence of C-H stretching in alkanes. The spectra also showed major peaks at $1743 \mathrm{~cm}^{-1}, 1512 \mathrm{~cm}^{-1}, 1449 \mathrm{~cm}^{-}$ 1 , and $1222 \mathrm{~cm}^{-1}$ to be an indication of the presence of $\mathrm{C}=\mathrm{O}, \mathrm{C}=\mathrm{C}$ stretching vibration of cyclic alkene, $\mathrm{N}=\mathrm{O}$ bending in nitro groups and $\mathrm{C}-\mathrm{N}$ in amine compound respectively $[31,59]$.
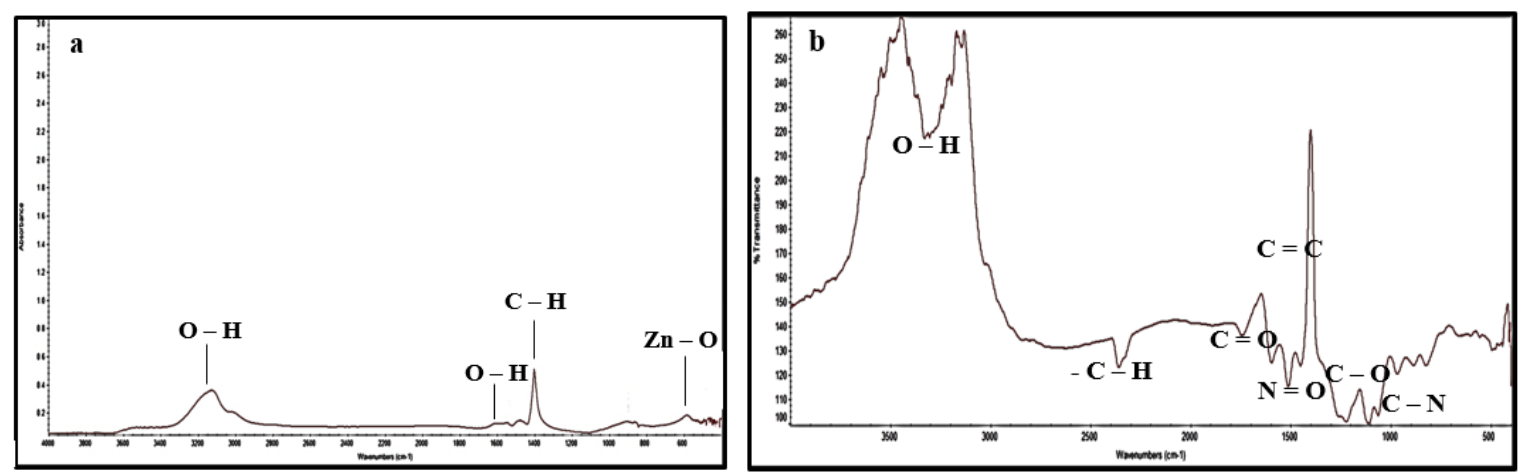

Figure 7. FT-IR spectrum of (a) L-ZnO-NPs and (b) RCH. 


\subsection{Batch adsorption studies.}

\subsubsection{Effect of adsorption parameters.}

The effect of sorbent mass, $\mathrm{pH}$, and initial sorbate concentrations were varied to determine the percentage removal and sorption capacity of both L-ZnO-NPs and C-ZnO-NPs by $\mathrm{RCH}$, which are illustrated in Figure 8.

The sorbent mass was varied from $0.5 \mathrm{~g}$ to $2.5 \mathrm{~g}$ at a constant $\mathrm{pH}$ of 6.0 , stirred at 450 rpm for $60 \mathrm{~min}$. The concentration of the sorbate solutions was kept at $2.03 \mathrm{mg} / \mathrm{l}$ and $1.72 \mathrm{mg} / \mathrm{l}$ for L-ZnO-NPs and C-ZnO-NPs, respectively. According to Figure 8a, the percentage removal of both $\mathrm{ZnO}-\mathrm{NPs}$ increased with increasing sorbent mass until equilibrium was attained at 2.0 $\mathrm{g}$ with a maximum percentage removal of $88.56 \%$ and $90.05 \%$ for $\mathrm{L}-\mathrm{ZnO}-\mathrm{NPs}$ and $\mathrm{C}-\mathrm{ZnO}-$ NPs respectively. This significant increase in percentage removal was due to the increased active sites as well as greater surface availability for the uptake of the sorbate ions [60-61]. The percentage of adsorption suddenly decreased slightly for both sorbate solutions $(88.12 \%$ and $88.90 \%)$ as the sorbent mass increased to $2.5 \mathrm{~g}$. On the contrary, the sorption efficiency $\left(\mathrm{q}_{\mathrm{e}}\right)$ was inversely proportional to the sorbent mass as the lowest efficiency $(0.04 \mathrm{mg} / \mathrm{g}$ and 0.03 $\mathrm{mg} / \mathrm{g}$ ) for $\mathrm{L}-\mathrm{ZnO}$ and $\mathrm{C}-\mathrm{ZnO}$ NPs respectively was recorded at the maximum sorbent mass of $2.5 \mathrm{~g}$. This effect may be attributed to the difficulty in the mass transfer, as well as the unsaturation and screening effect of the surface area of the sorbent [62-64].

The $\mathrm{pH}$ of the sorbate solution was varied between 2-13 at an initial concentration of $2.03 \mathrm{mg} / \mathrm{l}$ and $1.72 \mathrm{mg} / \mathrm{l}$ for L-ZnO-NPs and C-ZnO-NPs, respectively. The sorbent mass (0.5 $\mathrm{g})$, stirring rate $(450 \mathrm{rpm})$, and time $(60 \mathrm{~min})$ were all kept constant. The $\mathrm{pH}$ changes of the medium usually influence the surface reactivity of the sorbent through the uptake of the sorbate ions through hydrogen bonding and/or ion exchange mechanisms [65-66]. According to Figure $8 \mathrm{~b}$, the highest and lowest percentage of removal was observed at a $\mathrm{pH}$ of 8 and 2 for both sorbate solutions. At lower $\mathrm{pH}$, active sites are protonated, leading to high electrostatic repulsion between the sorbate ions and the active sites resulting in lower uptake. However, as $\mathrm{pH}$ increases to the optimum level of 8 , hydrogen ions $\left(\mathrm{H}^{+}\right)$decrease, which enables the sorbate ions to bind to the increasing negative surface charge of the sorbent [34,61]. Precipitation of metal hydroxide species $\left[\mathrm{Zn}(\mathrm{OH})_{2}\right]$ occurs beyond the optimum $\mathrm{pH}$, which competes with the sorbate ions for an active site for attachments [67]. Besides, agglomeration/aggregation of the $\mathrm{L}-\mathrm{ZnO}-\mathrm{NPs}$ also contributed to the difference in the uptake of the two sorbate ions.

The variation in $\%$ sorbate removal with contact time given different initial concentrations ranging from 0.46-1.45 $\mathrm{mg} / \mathrm{l}$ and $0.50-1.74 \mathrm{mg} / \mathrm{l}$ for $\mathrm{L}-\mathrm{ZnO}$ and $\mathrm{C}-\mathrm{ZnO} \mathrm{NPs}$ sorbate solutions respectively is shown in Figure 8 (c \& d). The sorbent mass $(0.5 \mathrm{~g})$, stirring rate $(450 \mathrm{rpm})$, and $\mathrm{pH}(6.0)$ were all kept constant. The percentage removal of sorbate ions remarkably increased for the first 80 minutes before showing a decreasing trend for all the concentrations in both sorbate solutions. The average \% removal increased from $83.7 \%$ to $88.0 \%(0.04-0.13 \mathrm{mg} / \mathrm{g})$ for L-ZnO-NPs and $85.6 \%$ to $88.8 \%(0.04-0.16 \mathrm{mg} / \mathrm{g})$ for C-ZnO-NPs as initial concentrations of the sorbate solution increases. The increase in adsorption efficiency may likely be attributed to the driving force of mass transfer or diffusion processes from the bulk to the surface $[25,68]$. However, beyond the equilibrium point, the adsorption sites got exhausted, leading to a decrease in the efficiency of $\mathrm{RCH}$ [69]. Adsorption at lower and higher concentrations tends to be slightly proportional according to the data set since at higher concentrations. Active sites tend to be slightly saturated as compared to lower concentrations. 

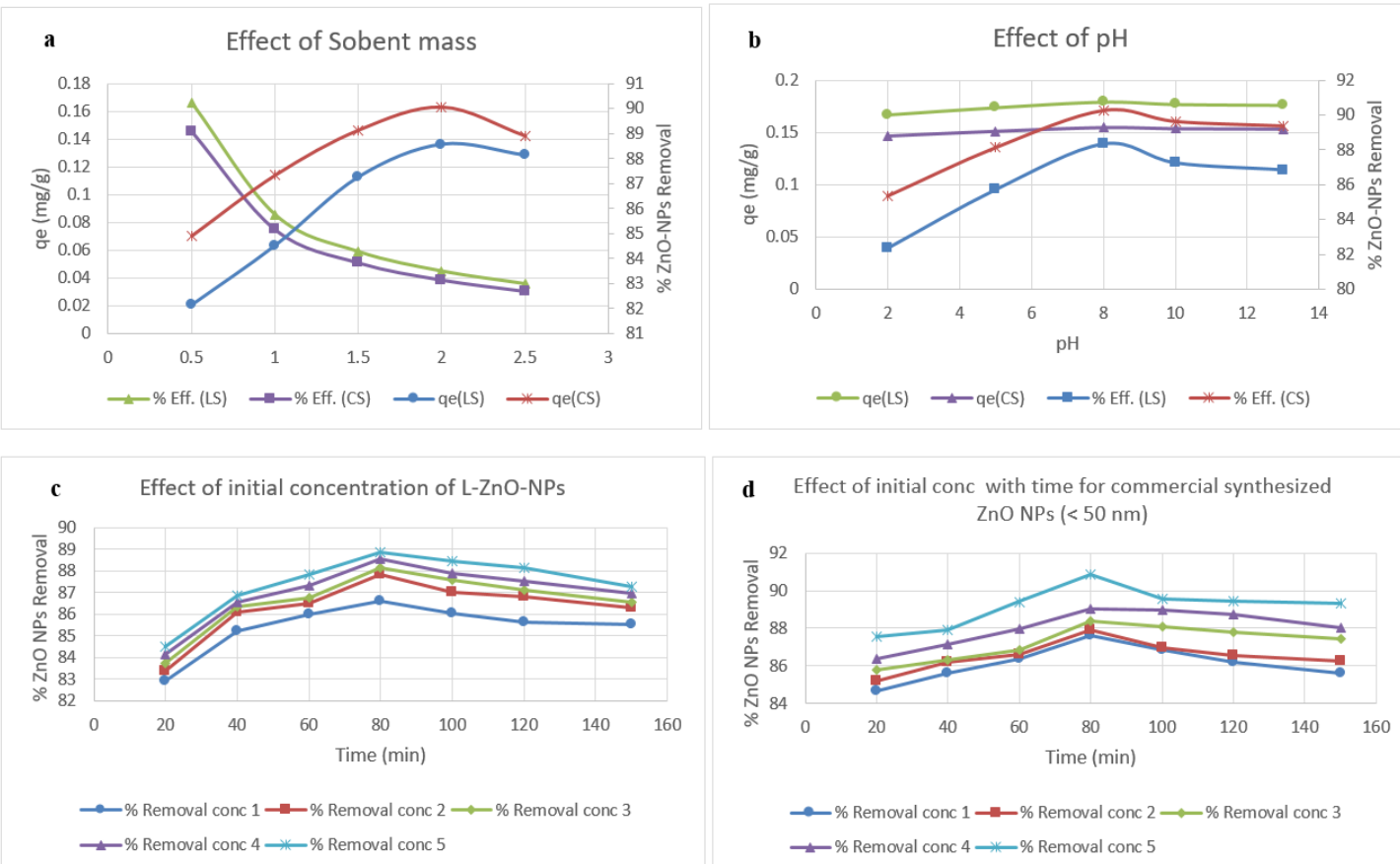

Figure 8. Effect of (a) sorbent mass (b) pH on L-ZnO and C-ZnO NPs sorption on RCH (c \& d) initial concentration ( $\mathrm{L}-\mathrm{ZnO} \& \mathrm{C}-\mathrm{ZnO}-\mathrm{NPs})$.

\subsection{Isothermal studies.}

Equilibrium data analysis for the sorption of sorbate solutions ( $\mathrm{L}-\mathrm{ZnO} \& \mathrm{C}-\mathrm{ZnO}-\mathrm{NPs}$ ) onto RCH was carried out using three isotherm models shown in Table 2.

Table 2. Langmuir, Freundlich and Temkin parameters for L-ZnO-NPs and C-ZnO-NPs uptake,

\begin{tabular}{l|c|c} 
Parameters & L-ZnO-NPs & C-ZnO-NPs \\
\hline Langmuir isotherm $\left(\frac{\mathbf{1}}{\boldsymbol{q}_{\boldsymbol{e}}}=\left[\frac{\mathbf{1}}{\boldsymbol{Q}_{\boldsymbol{o}}}\right] \frac{\mathbf{1}}{\boldsymbol{C}_{\boldsymbol{e}}}+\frac{\mathbf{1}}{\boldsymbol{Q}_{\boldsymbol{o}}}\right)$ & & \\
\hline $\mathrm{Q}_{\mathrm{o}}[\mathrm{mg} / \mathrm{g}]$ & 0.797 & 0.710 \\
\hline $\mathrm{K},[\mathrm{L} / \mathrm{g}]$ & 0.430 & 0.396 \\
\hline $\mathrm{R}^{2}$ & 1.00 & 0.996 \\
\hline & & \\
\hline Freundlich isotherm $\left(\log \boldsymbol{q}_{\boldsymbol{e}}=\log \boldsymbol{K}_{\boldsymbol{f}}+\frac{\mathbf{1}}{\boldsymbol{n}} \log \boldsymbol{C}_{\boldsymbol{e}}\right)$ & & \\
\hline $\mathrm{K}_{\mathrm{f}}[\mathrm{L} / \mathrm{g}]$ & 1.084 & 0.896 \\
\hline $\mathrm{n}$ & 1.166 & 1.246 \\
\hline $\mathrm{R}^{2}$ & 0.999 & 0.986 \\
\hline Temkin isotherm $\left(\boldsymbol{q}_{\boldsymbol{e}}=\boldsymbol{B}_{\boldsymbol{T}} \boldsymbol{I n} \boldsymbol{A}_{\boldsymbol{T}}+\boldsymbol{B}_{\boldsymbol{T}} \boldsymbol{I n} \boldsymbol{C}_{\boldsymbol{e}}\right)$ & & \\
\hline $\mathrm{A}_{\mathrm{T}},[\mathrm{L} / \mathrm{g}]$ & 0.764 & 0.663 \\
\hline $\mathrm{B}_{\mathrm{T}}$ & 11.40 & 6.658 \\
\hline $\mathrm{b}_{\mathrm{T}}$ & 220.90 & 378.34 \\
\hline $\mathrm{R}^{2}$ & 0.958 & 0.799
\end{tabular}

From Table 2, Langmuir and Freundlich's models fit best for L-ZnO-NPs, whereas, in the case of C-ZnO-NPs, Langmuir model was considered to be the best fit based on their correlation coefficients $\left(\mathrm{R}^{2}\right)$. With reference to the Langmuir isotherm model, the sorption of $\mathrm{ZnO}-\mathrm{NPs}$ onto $\mathrm{RCH}$ was monolayer occurring on a homogenous surface. The theoretical sorption capacity $\left(\mathrm{Q}_{\mathrm{o}}\right.$ ) recorded for this model was $0.797 \mathrm{mg} / \mathrm{g}$ and $0.710 \mathrm{mg} / \mathrm{g}$ for L-ZnO-NPs and $\mathrm{C}-\mathrm{ZnO}-\mathrm{NPs}$, respectively. This presupposes that the potential for $\mathrm{RCH}$ to remove $\mathrm{L}-\mathrm{ZnO}-$ NPs from aqueous solution was higher than L-ZnO-NPs. However, Langmuir isotherm best fitted for a study by [70] with a sorption capacity ranged between $1.0 \times 10^{-4}$ to $3.9 \times 10^{-4}$ $\mathrm{mg} / \mathrm{g}$ for the removal of $\mathrm{Cu}, \mathrm{Cd}, \mathrm{Fe}, \mathrm{Cr}$, and $\mathrm{Pb}$ ions respectively from aqueous solution using 
coconut husk. Meanwhile, the calculated separation factor $\left.\mathrm{R}_{\mathrm{L}}\right)$ illustrated in Table 3 for this isotherm model for both sorbates was between 0 and 1 , indicating favorable sorption.

Table 3. Separation factor $\left(\mathrm{R}_{\mathrm{L}}\right)$ for $\mathrm{L}-\mathrm{ZnO}-\mathrm{NPs}$ and C-ZnO-NPs uptake.

\begin{tabular}{c|c|c|c}
{$\left[\mathbf{C}_{\mathbf{0}}\right] \mathbf{L - Z n O}-\mathbf{N P s}(\mathbf{m g} / \mathbf{l})$} & $\mathbf{R}_{\mathbf{L}}$. L-ZnO-NPs & {$\left[\mathbf{C}_{\mathbf{o}}\right] \mathbf{C - Z n O - N P s}(\mathbf{m g} / \mathbf{l})$} & $\mathbf{R}_{\mathbf{L}}$. C-ZnO-NPs \\
\hline 0.462 & 0.846 & 0.501 & 0.835 \\
\hline 0.884 & 0.741 & 0.844 & 0.750 \\
\hline 1.045 & 0.708 & 1.247 & 0.670 \\
\hline 1.259 & 0.668 & 1.523 & 0.624 \\
\hline 1.451 & 0.635 & 1.736 & 0.593
\end{tabular}

The n-value from the Freundlich isotherm model demonstrates the degree of non-linear mechanism between the sorbate solution and the sorbent. When $\mathrm{n}=1$, it describes the linearity of the process. If $n<1$, suggests that the sorption process is unfavorable, and if $n>1$, the sorption process is considered to be favorable [71-72]. From the current study, the value of $n$ for the two sorbate solutions $(1.166 \& 1.246)$ is greater than unity suggesting the favourability of the process.

Temkin model assumes chemical sorption is favorable when a linear decrease occurs in the sorption energy between the interactions between the sorbent and sorbate [73]. The correlation coefficients of 0.958 and 0.799 recorded for the two sorbate solutions in this study do not fit well for the sorption process.
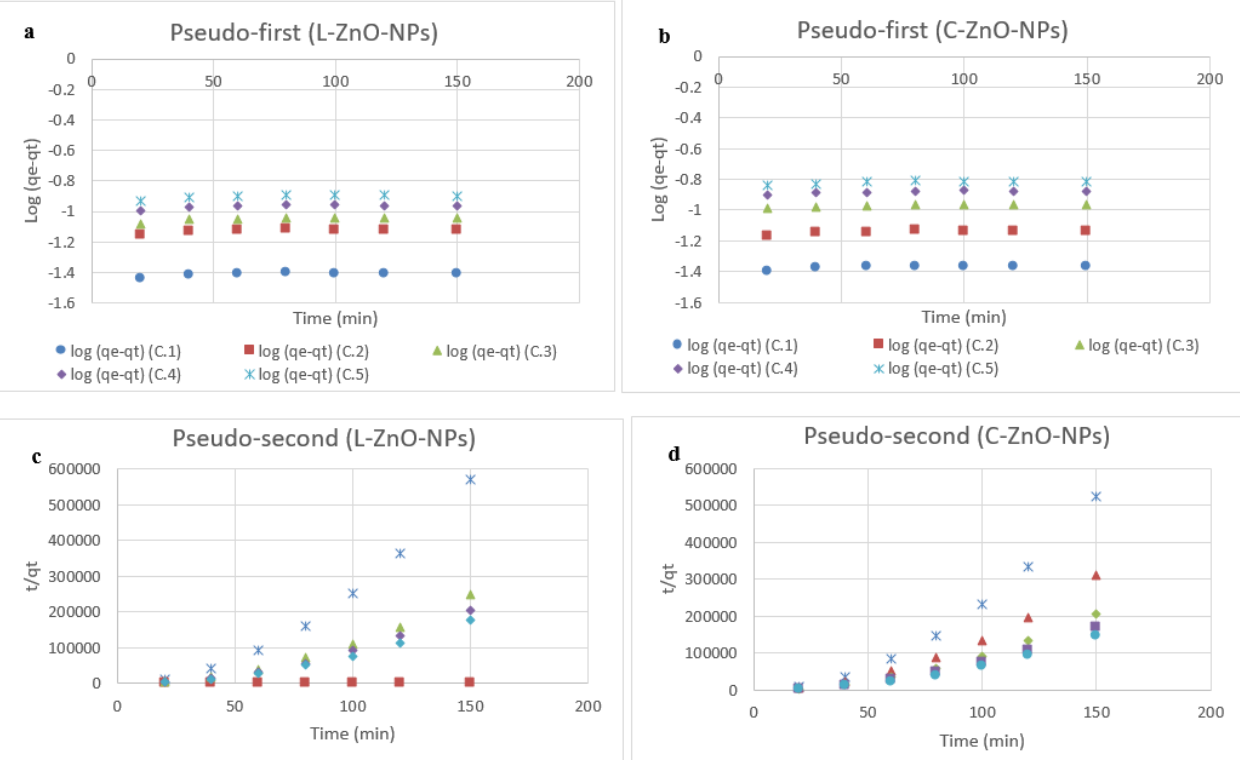

$* \mathrm{t} / \mathrm{qt}$ (Conc. 1) $-\mathrm{t} / \mathrm{qt}$ (Conc. 2) $\Delta \mathrm{t} / \mathrm{qt}$ (Conc. 3) $\bullet \mathrm{t} / \mathrm{qt}$ (Conc. 4) $\bullet \mathrm{t} / \mathrm{qt}$ (Conc. 5)
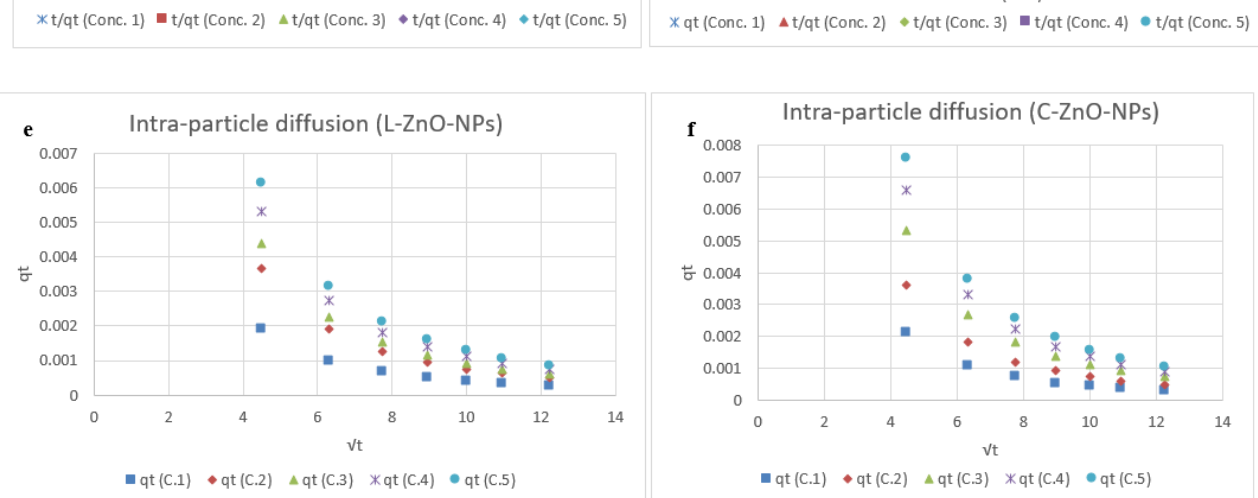

Figure 9. (a) Pseudo-first [L-ZnO-NPs] (b) Pseudo-first [C-ZnO-NPs] (c) Pseudo-second [L-ZnO-NPs] (d) Pseudo-second [C-ZnO-NPs] (e) Intra-particle diffusion [L-ZnO-NPs] (f) Intra-particle diffusion [C-ZnO-NPs] kinetic plots for adsorption of $\mathrm{ZnO}-\mathrm{NPs}$ onto $\mathrm{RCH}$. 
Table 4. Adsorption kinetic parameters for L-ZnO-NPs and C-ZnO-NPs.

\begin{tabular}{|c|c|c|c|c|c|c|c|c|c|c|}
\hline \multirow[t]{2}{*}{$\begin{array}{c}\text { Initial } \\
\text { conc, } \mathrm{C}_{0} \\
{[\mathrm{mg} / \mathrm{l}]}\end{array}$} & \multicolumn{4}{|c|}{$\begin{array}{c}\text { Pseudo-first order } \\
\left(\log \left(q_{\theta}-q_{t}\right)=\log q_{\theta}-\frac{k_{1} t}{2.303}\right)\end{array}$} & \multicolumn{3}{|c|}{$\begin{array}{l}\text { Pseudo-second order } \\
\qquad\left(\frac{t}{q_{t}}=\frac{1}{k_{2} q_{\theta}^{2}}+\frac{t}{q_{\theta}}\right)\end{array}$} & \multicolumn{3}{|c|}{$\begin{array}{l}\text { Intra-particle diffusion } \\
\qquad\left(q_{t}=k_{i d} \sqrt{t}+I\right)\end{array}$} \\
\hline & $\begin{array}{l}\text { Q qe.theo. } \\
\text { (mg/g) }\end{array}$ & $\begin{array}{c}\mathbf{k}_{1} \\
\left(\mathbf{m i n}^{-1}\right)\end{array}$ & $\mathbf{R}^{2}$ & $\begin{array}{c}\begin{array}{c}\text { qe.exp }_{\text {exp }} \\
(\mathrm{mg} / \mathrm{g})\end{array} \\
\end{array}$ & $\begin{array}{c}\begin{array}{c}\text { qe.theo } \\
\text { (mg/g) }\end{array} \\
\end{array}$ & $\begin{array}{c}\mathbf{k}_{2} \\
\text { (g/mg.min) }\end{array}$ & $\mathbf{R}^{2}$ & $\begin{array}{c}\mathbf{K}_{\mathbf{i d}}(\mathrm{mg} /(\mathrm{g} \\
\left.\min ^{1 / 2}\right)\end{array}$ & $\begin{array}{c}\mathbf{I} \\
(\mathrm{mg} / \mathrm{g})\end{array}$ & $\mathbf{R}^{2}$ \\
\hline $\begin{array}{c}\text { L-ZnO- } \\
\text { NP } \\
0.462 \\
0.884 \\
1.045 \\
1.259 \\
1.451\end{array}$ & $\begin{array}{l}0.037 \\
0.072 \\
0.085 \\
0.103 \\
0.119\end{array}$ & $\begin{array}{c}4.61 \times \\
10^{-4} \\
4.61 \times \\
10^{-4} \\
4.61 \times \\
10^{-4} \\
4.61 \times \\
10^{-4} \\
4.61 \times \\
10^{-4}\end{array}$ & $\begin{array}{l}0.511 \\
0.514 \\
0.516 \\
0.517 \\
0.523\end{array}$ & $\begin{array}{l}0.039 \\
0.076 \\
0.090 \\
0.110 \\
0.127\end{array}$ & $\begin{array}{c}2.34 \times \\
10^{-4} \\
0.087 \\
5.38 \times \\
10^{-4} \\
6.51 \times \\
10^{-4} \\
7.54 \times \\
10^{-4}\end{array}$ & $\begin{array}{c}7.40 \times 10^{-6} \\
0.383 \\
1.70 \times 10^{-5} \\
2.05 \times 10^{-5} \\
2.38 \times 10^{-5}\end{array}$ & $\begin{array}{l}0.947 \\
0.999 \\
0.946 \\
0.946 \\
0.946\end{array}$ & $\begin{array}{c}2.00 \times \\
10^{-4} \\
4.00 \times \\
10^{-4} \\
4.00 \times \\
10^{-4} \\
5.00 \times \\
10^{-4} \\
6.00 \times \\
10^{-4}\end{array}$ & $\begin{array}{c}2.40 \times \\
10^{-3} \\
4.70 \times \\
10^{-3} \\
5.50 \times \\
10^{-3} \\
6.70 \times \\
10^{-3} \\
7.80 \times \\
10^{-3}\end{array}$ & $\begin{array}{l}0.837 \\
0.838 \\
0.838 \\
0.837 \\
0.837\end{array}$ \\
\hline $\begin{array}{c}\text { C-ZnO- } \\
\text { NP } \\
0.501 \\
0.844 \\
1.247 \\
1.523 \\
1.736\end{array}$ & $\begin{array}{l}0.041 \\
0.070 \\
0.103 \\
0.127 \\
0.147\end{array}$ & $\begin{array}{c}4.61 \times \\
10^{-4} \\
4.61 \times \\
10^{-4} \\
4.61 \times \\
10^{-4} \\
4.61 \times \\
10^{-4} \\
4.61 \times \\
10^{-4}\end{array}$ & $\begin{array}{l}0.466 \\
0.507 \\
0.673 \\
0.633 \\
0.583\end{array}$ & $\begin{array}{l}0.043 \\
0.073 \\
0.108 \\
0.134 \\
0.155\end{array}$ & $\begin{array}{c}2.55 \times \\
10^{-4} \\
4.32 \times \\
10^{-4} \\
6.48 \times \\
10^{-4} \\
7.97 \times \\
10^{-4} \\
9.20 \times \\
10^{-4}\end{array}$ & $\begin{array}{l}8.02 \times 10^{-6} \\
1.36 \times 10^{-5} \\
2.05 \times 10^{-5} \\
2.52 \times 10^{-5} \\
2.91 \times 10^{-5}\end{array}$ & $\begin{array}{l}0.946 \\
0.947 \\
0.947 \\
0.947 \\
0.947\end{array}$ & $\begin{array}{c}2.00 \times \\
10^{-4} \\
4.00 \times \\
10^{-4} \\
5.00 \times \\
10^{-4} \\
7.00 \times \\
10^{-4} \\
8.00 \times \\
10^{-4}\end{array}$ & $\begin{array}{c}2.70 \times \\
10^{-3} \\
4.50 \times \\
10^{-3} \\
6.70 \times \\
10^{-3} \\
8.30 \times \\
10^{-3} \\
9.60 \times \\
10^{-3}\end{array}$ & $\begin{array}{l}0.832 \\
0.832 \\
0.829 \\
0.830 \\
0.830\end{array}$ \\
\hline
\end{tabular}

Table 5. Thermodynamic studies of L-ZnO-NPs and C-ZnO-NPs adsorption onto RCH.

\begin{tabular}{|c|c|c|c|c|c|c|c|c|c|c|c|}
\hline $\begin{array}{c}\mathrm{C}_{\mathrm{o}} \\
(\mathrm{mg} / \mathrm{l})\end{array}$ & $\begin{array}{c}\mathbf{T} \\
(\mathbf{K})\end{array}$ & $\begin{array}{c}\Delta \mathbf{G}^{\mathbf{o}} \\
\left(\mathrm{kJmol}^{-1}\right)\end{array}$ & $\begin{array}{c}\Delta \mathbf{S}^{\mathbf{o}} \\
\left(\mathbf{J K}^{-1}\right. \\
\left.\mathbf{m o l}^{-1}\right)\end{array}$ & $\begin{array}{c}\Delta \mathbf{H}^{\mathbf{0}} \\
(\mathbf{k J m o l} \\
\left.{ }_{1}\right)\end{array}$ & $\mathbf{R}^{2}$ & $\begin{array}{c}\mathrm{C}_{0} \\
(\mathrm{mg} / \mathrm{l})\end{array}$ & $\begin{array}{c}\mathbf{T} \\
(\mathbf{K})\end{array}$ & $\begin{array}{c}\Delta \mathbf{G}^{\mathbf{0}} \\
(\mathbf{k J m o l} \\
\left.\mathbf{1}^{-}\right)\end{array}$ & $\begin{array}{c}\Delta \mathbf{S}^{\mathbf{o}} \\
\left(\mathbf{J K}^{-1}\right. \\
\left.\mathbf{m o l}^{-1}\right)\end{array}$ & $\begin{array}{c}\Delta \mathbf{H}^{\mathbf{0}} \\
\left(\begin{array}{c}\mathbf{k J m o l} \\
\left.{ }_{1}\right)\end{array}\right.\end{array}$ & $\mathbf{R}^{2}$ \\
\hline $\begin{array}{l}\text { L-ZnO- } \\
\text { NPs }\end{array}$ & & & \multirow{7}{*}{7.82} & \multirow{7}{*}{-3893.78} & \multirow{7}{*}{0.564} & $\begin{array}{c}\text { C-ZnO- } \\
\text { NPs }\end{array}$ & & & \multirow{7}{*}{7.88} & \multirow{7}{*}{-3572.86} & \multirow{7}{*}{0.526} \\
\hline \multirow[t]{6}{*}{0.462} & 298 & 1734.67 & & & & \multirow[t]{6}{*}{0.622} & 298 & 1386.69 & & & \\
\hline & 303 & 1550.58 & & & & & 303 & 1189.06 & & & \\
\hline & 313 & 1298.94 & & & & & 313 & 1025.81 & & & \\
\hline & 323 & 1097.98 & & & & & 323 & 712.06 & & & \\
\hline & 333 & 1281.88 & & & & & 333 & 982.89 & & & \\
\hline & 343 & 1443.73 & & & & & 343 & 1074.88 & & & \\
\hline \multirow[t]{6}{*}{0.884} & 298 & 1388.04 & \multirow{6}{*}{2.16} & \multirow{6}{*}{-1816.03} & \multirow{6}{*}{0.302} & \multirow[t]{6}{*}{0.837} & 298 & 1212.03 & \multirow{6}{*}{10.56} & \multirow{6}{*}{-4257.52} & \multirow{6}{*}{0.602} \\
\hline & 303 & 1059.45 & & & & & 303 & 1102.69 & & & \\
\hline & 313 & 1003.40 & & & & & 313 & 943.76 & & & \\
\hline & 323 & 1002.68 & & & & & 323 & 492.96 & & & \\
\hline & 333 & 1109.32 & & & & & 333 & 738.85 & & & \\
\hline & 343 & 1210.55 & & & & & 343 & 856.50 & & & \\
\hline \multirow[t]{6}{*}{1.045} & 298 & 1333.27 & \multirow{6}{*}{3.13} & \multirow{6}{*}{-2079.50} & \multirow{6}{*}{0.416} & \multirow[t]{6}{*}{1.215} & 298 & 1167.37 & \multirow{6}{*}{13.31} & \multirow{6}{*}{-5034.79} & \multirow{6}{*}{0.703} \\
\hline & 303 & 1051.24 & & & & & 303 & 1064.56 & & & \\
\hline & 313 & 966.38 & & & & & 313 & 818.21 & & & \\
\hline & 323 & 964.57 & & & & & 323 & 425.79 & & & \\
\hline & 333 & 1035.31 & & & & & 333 & 570.03 & & & \\
\hline & 343 & 1134.76 & & & & & 343 & 701.01 & & & \\
\hline \multirow[t]{6}{*}{1.259} & 298 & 1293.51 & \multirow{6}{*}{4.90} & \multirow{6}{*}{-2568.11} & & 1.474 & 298 & 1095.12 & & & \\
\hline & 303 & 1021.12 & & & & & 303 & 978.83 & & & \\
\hline & 313 & 903.99 & & & 0.495 & & 313 & 704.72 & 13.36 & -4964.37 & 0.703 \\
\hline & 323 & 841.37 & & & & & 323 & 351.88 & & & \\
\hline & 333 & 941.45 & & & & & 333 & 501.12 & & & \\
\hline & 343 & 1034.18 & & & & & 343 & 606.17 & & & \\
\hline 1.451 & 298 & 1186.03 & & & & 1.621 & 298 & 1016.74 & & & \\
\hline & 303 & 929.71 & & & & & 303 & 885.88 & & & \\
\hline & 313 & 785.51 & 4.25 & -2261.57 & 0.381 & & 313 & 550.01 & 13.63 & -4945.92 & 0.644 \\
\hline & 323 & 701.37 & & & & & 323 & 257.62 & & & \\
\hline & 333 & 864.68 & & & & & 333 & 354.33 & & & \\
\hline & 343 & 967.86 & & & & & 343 & 531.93 & & & \\
\hline
\end{tabular}

\subsection{Kinetic studies.}

Three kinetic models, thus pseudo-first-order, pseudo-second-order, and intra-particle diffusion models, were applied to evaluate the controlling mechanism of both sorbate solutions ( $\mathrm{L}-\mathrm{ZnO}-\mathrm{NPs}$ and C-ZnO-NPs) onto $\mathrm{RCH}$. The calculated rate constants and their correlation 
coefficients are illustrated in Table 4 with Figure 9 graphically show the plots of time with their initial sorbate concentrations.

Pseudo-second order was the appropriate model that describes the process based on their correlation coefficient $\left(\mathrm{R}^{2}\right)$ values, which are closer to unity despite their estimated experimental $\mathrm{q}_{\mathrm{e}}$ values, which are far below the theoretical $\mathrm{q}_{\mathrm{e}}$ values. However, experimental $\mathrm{q}_{\mathrm{e}}$ values of the pseudo-first-order model were quite close to the experimental values shown in Table 4. Although the pseudo-first-order rate showed a poor correlation coefficient of 0.52 , the intra-particle diffusion model records a slightly higher correlation coefficient $(0.84)$ than pseudo-first-order but lower than pseudo-second-order (0.95). This presupposes that intraparticle diffusion cannot solely describe the sorption of $\mathrm{ZnO}-\mathrm{NPs}$ onto $\mathrm{RCH}$ as the plotted lines do not pass through the origin. The plot displayed a multi-linear nature (Fig 9 e \& f) for the experimental data confirming the sorption mechanism to be in two steps [74]. The two steps of the curve might be due to the boundary layer diffusion effect and intra-particle diffusion effect [75]. The thickness of the boundary layer expressed by the intercept (I) is lower in this study indicating minimal boundary layer effect. The calculated values of intra-particle diffusion rate constant, $\mathrm{K}_{\text {id }}$ decreases with increasing sorbate concentrations, as illustrated in Table 4.

\subsection{Thermodynamic studies.}

The removal of $\mathrm{ZnO}-\mathrm{NPs}$ by $\mathrm{RCH}$ as sorbent was determined at temperature ranges of 298-343 K for five initial sorbate concentrations and the thermodynamic variables [Gibbs free energy $\left(\Delta \mathrm{G}^{\circ}\right)$, enthalpy change $\left(\Delta \mathrm{H}^{\circ}\right)$ and entropy change $\left.\left(\Delta \mathrm{S}^{\circ}\right)\right]$ as well as their calculated correlation coefficients are illustrated in Table 5.

The positive values of $\Delta \mathrm{G}^{\mathrm{o}}$ obtained for both sorbates at the different temperatures reveal a non-spontaneous sorption process, which requires an external source of energy. On the other hand, positive values recorded for $\Delta \mathrm{S}^{\circ}$ demonstrates the occurrence of a degree of freedom at the $\mathrm{RCH}-\mathrm{ZnO}-\mathrm{NPs}$ solution interface during the sorption process. It also suggests an increase in the randomness and affinity of the sorbate solution towards RCH [29]. Meanwhile, the negative values recorded for $\Delta \mathrm{H}^{\circ}$ confirms the exothermic nature of the sorption process as the high $\Delta \mathrm{H}^{\circ}$ values suggests a chemical sorption process.

\section{Conclusions}

Zinc oxide NPs were successfully synthesized through a solvothermal method with spherical shaped morphology. Characterization by XRD, FE-SEM, TEM revealed the crystallite and average particle size to be $14.7 \mathrm{~nm}, 36.0 \mathrm{~nm}$, and $24.0 \mathrm{~nm}$, respectively. The surface area of the sorbent $(\mathrm{RCH})$ determined through BET analysis revealed a size of 2.60 $\mathrm{m}^{2} / \mathrm{g}$ with a porous surface nature. FT-IR confirmed functional groups such as hydroxyl, carboxyl, and nitro groups as present on the sorbent. The morphology of the sorbate particles in solution been agglomerated slightly influenced the sorption capacity of the $\mathrm{RCH}$ as the uptake of L-ZnO-NPs onto RCH was lesser as compared to C-ZnO-NPs. The optimum sorbent mass to remove $88 \%$ and $90 \%$ of $\mathrm{L}-\mathrm{ZnO}-\mathrm{NPs}$ and $\mathrm{C}-\mathrm{ZnO}-\mathrm{NPs}$, respectively, is $2.0 \mathrm{~g}$. Adsorption efficiency increased with an increase in initial sorbate concentration to the $80^{\text {th }}$ minute when maximum removal was obtained $(0.13 \mathrm{mg} / \mathrm{g}$ and $0.16 \mathrm{mg} / \mathrm{g}$ for L-and C-ZnONPs) at an optimum $\mathrm{pH}$ of 8. Langmuir and Freundlich isotherm models fitted best for L-ZnONPs with maximum sorption capacity of $0.78 \mathrm{mg} / \mathrm{g}$, whereas the Langmuir model also fitted well for C-ZnO-NPs with maximum sorption capacity of $0.71 \mathrm{mg} / \mathrm{g}$. The sorption process was identified to be exothermic with non-spontaneous and random sorption processes, which was 
best described by the pseudo-second-order model. However, the lignocellulose material used in this study could help alleviate the pollution effect of water bodies with these nanoparticles that are very difficult to eliminate due to their sizes.

\section{Funding}

This research received no external funding.

\section{Acknowledgments}

The authors acknowledge the contribution of colleagues from the Faculty of Resource Science and Technology (FRST) Geochemistry Laboratory and Analytical Laboratory, Universiti Malaysia Sarawak, and Departments of Science, Kibi Presbyterian College of Education, Kibi, Eastern Region, Ghana.

\section{Conflicts of Interest}

The authors declare that they have no competing interests regarding the publication of this manuscript. Also, issues of plagiarism, data fabrication and or falsification, double publication, and or submission have been completely observed by the authors. EK Droepenu and EA Asare undertook the collection of the coconut husk. EK Droepenu, AE Asare, and AO Gyampoh designed the research. EK Droepenu carried out the laboratory work. EK Droepenu, AE Asare, AO Gyampo, E Kumi-Arhin, SB Dampare, and DK Adotey conducted the review and editing. Finally, all authors have read and approved the manuscript for publication.

\section{References}

1. Broomfield, M.; Hansen, S.F.; Pelsy, F. Support for 3rd regulatory review on nanomaterials-environmental legislation. Project Report. European Commission 2016, https://doi.org/10.2779/49879.

2. Sarmah, K.; Pratihar, S. Synthesis, characterization and photocatalytic application of iron oxalate capped Fe, $\mathrm{Fe}-\mathrm{Cu}$, Fe-Co, and Fe-Mn oxide nanomaterial. ACS Sustain. Chem. Eng. 2017, 5, 310-324, https://doi.org/10.1021/acssuschemeng.6b01673.

3. Chen, H.; Zhao, L.; Wang, G.; Fang, W. Direct growth of ZnO nanorods on biogenic hierarchical rice husk $\mathrm{SiO}_{2}$ and their application to dye degradation. Clean Techn. Environ. Policy 2017, 19, 1335-1345, https://doi.org/10.1007/s10098-017-1332-2.

4. Zhao, Y.; Yu, N.; Dong, X.; Yan, H. Large area growth of ZnO Nanorods arrays on the stainless steel grid by aqueous solutions. Materials Research Innovations 2017, 21, 447-450, https://doi.org/10.1080/14328917.2016.1265261.

5. Husham, M.; Nizar, M.H.; Paiman, S.; Abuelsamen, A.A.; Farhat, O.F.; Al-Dulaimi, A.A. Synthesis of ZnO nanorods by microwave-assisted chemical-bath deposition for highly sensitive self-powered UV detection application. Sensor Act A 2017, 263, 166-173, https://doi.org/10.1016/j.sna.2017.05.041.

6. Jeem, M.; Zhang, L.; Ishioka, J.; Shibayama, T.; Iwasaki, T.; Kato, T.; Watanabe, S. Tuning optoelectrical properties of $\mathrm{ZnO}$ nanorods with excitonic defects via submerged illumination. Nano Lett. 2017, 17, 20882093, https://doi.org/10.1021/acs.nanolett.7b00324.

7. $\quad$ Das, P.; Sarmah, K.; Hussain, N.; Pratihar, S.; Das, S.; Bhattacharyya, P.; Patil, S.A.; Kim, H.S.; Iqbal, M.; Khazie, A.; Bhattacharyya, S.S. Novel synthesis of an iron oxalate capped iron oxide nanomaterial; a unique soil conditioner and slow release eco-friendly source of iron sustenance in plants. $R S C A d v .2016,6,103012-$ 103025, https://doi.org/10.1039/C6RA18840K.

8. Saranji, S.N. Controllable growth of $\mathrm{ZnO}$ nanorods via electrode position technique: towards UV photodetection. Journal of Physics D: Applied Physics 2016, 49.

9. Gottschalk, F.; Sun, T.Y.; Nowack, B. Environmental concentrations of engineered nanomaterials: review of modeling and analytical studies. Environ Pollut. 2013, 181, 287-300, https://doi.org/10.1016/j.envpol.2013.06.003.

10. Wahab, R.; Khan, F.; Singh, R.B.; Kaushik, N.K.; Ahmad, J.; Siddiqui, M.A.; Saquib, Q.; Ali, B.A.; Khan, S.T.; Musarrat, J.; Al-Khedhairy, A.A. Utilization of photocatalytic ZnO nanoparticles for deactivation of safranine dye and their applications for statistical analysis. Physica E: Low-dimensional Systems and Nanostructures 2015, 69, 101-108, https://doi.org/10.1016/j.physe.2015.01.005. 
11. Dwivedi, S.; Wahab, R.; Khan, F.; Mishra, Y.K.; Musarrat, J.; Al-Khedhairy, A.A. Reactive oxygen species mediated bacterial biofilm inhibition via zinc oxide nanoparticles and their statistical determination. PLoS ONE 2014, 9, 1-9, https://doi.org/10.1371/journal.pone.0111289.

12. Hölken, I. Complex shaped $\mathrm{ZnO}$ nano- and microstructure based polymer composites: mechanically stable and environmentally friendly coatings for potential antifouling applications. Phys. Chem. Chem. Phys. 2016, 18, 7114-7123, https://doi.org/10.1039/C5CP07451G.

13. Wahab, R.; Khan, F.; Mishra, Y.K.; Musarrat, J.; Al-Khedhairy, A.A. Antibacterial studies and statistical design set data of quasi zinc oxide nanostructures. RSC Adv. 2016a, 6, 32328-32339. https://doi.org/10.1039/C6RA05297E.

14. Wahab, R.; Kaushik, N.; Khan, F.; Kaushik, N.K.; Choi, E.H.; Musarrat, J.; Al-Khedhairy, A.A. Self-styled $\mathrm{ZnO}$ nanostructures promotes the cancer cell damage and suppresses the epithelial phenotype of glioblastoma. Sci. Rep. 2016b, 6, https://doi.org/10.1038/srep19950.

15. Wahab, R.; Siddiqui, M.A.; Saquib, Q.; Dwivedi, S.; Ahmad, J.; Musarrat, J.; Al-Khedhairy, A.A.; Shin, H.S. ZnO nanoparticles induced oxidative stress and apoptosis in HepG2 and MCF-7 cancer cells and their antibacterial activity. Colloids Surf. B Biointerfaces 2014, 117, 267-276, https://doi.org/10.1016/j.colsurfb.2014.02.038.

16. Antoine, T.E.; Hadigal, S.R.; Yakoub, A.M.; Mishra, Y.K.; Bhattacharya, P.; Haddad, C.; Valyi-Nagy, T.; Adelung, R.; Prabhakar, B.S.; Shukla, D. Intravaginal zinc oxide tetrapod nanoparticles as novel immuneprotective agents against genital herpes. J. Immunol. 2016, 196, 4566-4575, https://doi.org/10.4049/jimmunol.1502373.

17. Lee, K.M.; Lai, C.W.; Ngai, K.S.; Juan, J.C. Recent developments of zinc oxide based photocatalyst in water treatment technology: a review. Water Research 2016, 88, 428-448, https://doi.org/10.1016/j.watres.2015.09.045.

18. Sirelkhatim, A.; Mahmud, S.; Seeni, A.; Mohamad, N.H. Review on zinc oxide nanoparticles: antibacterial activity and toxicity mechanism. Nano-Micro Letters 2015, 7, 219-242, https://doi.org/10.1007/s40820-0150040-x.

19. Jiang, J.; Pi, J.; Cai, J. The Advancing of Zinc Oxide Nanoparticles for Biomedical Applications. Bioinorganic Chemistry and Applications 2018, 1-18, https://doi.org/10.1155/2018/1062562.

20. Qui, W.Z.; Yang, H.C.; Wan, L.S.; Xu, Z.K. Co-deposition of catechol/polyethyleneimine on porous membrane for efficient decolorization of dye water. J. Matter. Chem. A 2015, 3, 14438-14444, https://doi.org/10.1039/C5TA02590G.

21. Aljeboree, A.M.; Alshirifi, A.N.; Alkaim, A.F. Kinetics and equilibrium study for the adsorption of textile dye on coconut shell activated carbon. Arab. J. Chem. 2017, 10, 3381-3393, https://doi.org/10.1016/j.arabjc.2014.01.020.

22. Hao, J.; Li, C.; Hu, C.; Wu, K. Rapid, efficient and economic removal of organic dyes and heavy metals from wastewater by zinc-induced in-situ reduction and precipitation of graphene oxide. J. Taiwan Inst. Chem. Eng. 2018, 88, 137-145, https://doi.org/10.1016/j.jtice.2018.03.045.

23. Hadibarata, T.; Syafiuddin, A.; Al-Dhabaan, F.A.; Elshikh, M.S.; Rubiyatno. Biodegradation of Mordant orange-1 using newly isolated strain Trichoderma harzianum RY44 and its metabolite appraisal. Bioproc. Biosyst. Eng. 2018, 41, 621-632, https://doi.org/10.1007/s00449-018-1897-0.

24. El-Gohary, F.; Tawfik, A.; Mahmoud, U. Comparative study between chemical coagulation/precipitation (C/P) versus coagulation/dissolved air flotation (C/DAF) for pre-treatment of personal care products (PCPs) wastewater. Desalination 2010, 252, 106-112, https://doi.org/10.1016/j.desal.2009.10.016.

25. Wang, F.; Yang, W.; Cheng, P.; Zhang, S.; Zhang, S.; Jiao, W.; Sun, Y. Adsorption characteristics of cadmium onto microplastics from aqueous solutions. Chemosphere 2019, 235, 1073-1080, https://doi.org/10.1016/j.chemosphere.2019.06.196.

26. Al Farraj, D.A.; Hadibarata, T.; Yuniarto, A.; Syafiuddin, A.; Surtikanti, H.K.; Elshikh, M.S.; Al Khulaifi, M.M.; Al-Kufaidy, R. Characterization of pyrene and chrysene degradation by halophilic Hortaea sp. B15. Bioprocess Biosystems Eng. 2019, 42, 963-969, https://doi.org/10.1007/s00449-019-02096-8.

27. Kristanti, R.A.; Hadibarata, T.; Al Farraj, D.A.; Elshikh, M.S.; Alkufeidy, R.M. Biodegradation Mechanism of Phenanthrene by Halophilic Hortaea sp. B15. Water, Air, \& Soil Pollution 2018, 229, https://doi.org/10.1007/s11270-018-3969-9.

28. Gisi, S.D.; Lofrano, G.; Grassi, M.; Notarnicola, M. Characteristics and adsorption capacities of low-cost sorbent for wastewater treatment: A review. Sustain. Mat. Technol. 2016, 9, 10-40, https://doi.org/10.1016/j.susmat.2016.06.002.

29. Jain, S.N.; Gogate, P.R. Adsorption removal of acid violet dye from wastewater using biosorbent obtained from $\mathrm{NaOH}$ and $\mathrm{H}_{2} \mathrm{SO}_{4}$ activation of fallen leaves of Ficus racemose. J. Mol. Liq. 2017, 243, 132-143, https://doi.org/10.1016/j.molliq.2017.08.009.

30. Şentürk, İ.; Alzein, M. Adsorption of Acid Violet 17 onto Acid-Activated Pistachio Shell: Isotherm, Kinetic and Thermodynamic Studies. Acta Chim. Slov. 2020, 67, 1-15, https://doi.org/10.17344/acsi.2019.5195.

31. Azani, N.F.S.M.; Chuin, C.T.H.; Abdullah, N.S.; Sharifuddin, S.S.; Hussin, M.H. Characterisation and Kinetic Studies on Activated Carbon Derived from Rubber Seed Shell for the Removal of Methylene Blue in Aqueous Solutions. Journal of Physical Science 2019, 30, 1-20, https://doi.org/10.21315/jps2019.30.2.1. 
32. El Bardiji, N.; Ziat, K.; Saidi, M. Adsorption of copper from aqueous solution by Moroccan attapulgite: kinetic and thermodynamic studies. Int. J. Adv. Res. 2019, 7, 41-48, https://doi.org/10.21474/IJAR01/9972.

33. Aslam, M.; Rais, S.; Alam, M.; Pugazhendi, A. Adsorption of $\mathrm{Hg}$ (II) from Aqueous Solution Using Adulsa (Justicia adhatoda) Leaves Powder: Kinetic and Equilibrium Studies. Journal of Chemistry 2013, 2013, 1-11, https://doi.org/10.1155/2013/174807.

34. Vassileva, P.S.; Radoykova, T.H.; Detcheva, A.K.; Avramova, I.A.; Aleksieva, K.I.; Nenkova, S.K.; Valchev, I.V.; Mehandjiev, D.R. Adsorption of $\mathrm{Ag}^{+}$ions on hydrolysed lignocellulosic materials based on willow, paulownia, wheat straw and maize stalks. Int. J. Environ. Sci. Technol. 2016, 13, 1319-1328. https://doi.org/10.1007/s13762-016-0970-y.

35. Tran, H.D.; Vi, H.M.T.; Dang, H.T.T.; Narbaitz, R.M. Pollutant removal by Canna Generalis in tropical constructed wetlands for domestic wastewater treatment. Global J. Environ. Sci. Manage. 2019, 5, 331-344, https://doi.org/10.22034/gjesm.2019.03.06.

36. Aljeboree, A.M.; Alshirifi, A.N.; Alkaim, A.F. Kinetics and equilibrium study for the adsorption of textile dye on coconut shell activated carbon. Arab. J. Chem. 2017, 10, 3381-3393, https://doi.org/10.1016/j.arabjc.2014.01.020.

37. Taba, P.; Auliya, W.; Kasim, S.; Nafie, N.L.; Hala, Y. Adsorption of metal ion, Co(II) on Eucheuma spinosum. J. Phys.: Conf. Ser. 2019, 1341, 1-9, https://doi.org/10.1088/1742-6596/1341/3/032034.

38. Banerjee, M.; Basu, R.K.; Das, S.K. Cr(VI) adsorption by a green adsorbent walnut shell: adsorption studies, regeneration studies, scale-up design and economic feasibility. Process Safety and Environment Protection 2018, 116, 693-702, https://doi.org/10.1016/j.psep.2018.03.037.

39. Anuar, F.I.; Hadibarata, T.; Muryanto; Y.A.; Priyandoko, D.; Sari, A.A. Innovative chemically modified biosorbent for removal of procion red. Int. J. Technol. 2019, 10, 776-786, https://doi.org/10.14716/ijtech.v10i4.2398.

40. Belalia, M.; Bendjelloul, M.; Aziz, A.; Elandaloussi, E.H. Surface modification of olive stone waste for enhanced sorption properties of cadmium and lead ions. Acta chemica IASI 2018, 26, 281-306, https://doi.org/10.2478/achi-2018-0018.

41. Li, X.; Li, Y. Preparation and modification of biomass carbon and research of the adsorption of copper. IOP Conf. Series: Earth and Environmental Science 2019, 300, 1-6, https://doi.org/10.1088/17551315/300/5/052034.

42. Muin, N.A.A.; Maarof, H.I.; Bashah, N.A.A.; Zubir, N.A.; Alrozi, R.; Nasuha, N. Electrochemical Removal of Copper Ions Using Coconut Shell Activated Carbon. Indones. J. Chem. 2020, 20, 530-535, https://doi.org/10.22146/ijc.43077.

43. Bhatnagar, A.; Sillanpää, M.; Witek-Krowrak, A. Agricultural waste peels as versatile biomass for water purification: A review. Chem. Eng. J. 2015, 207, 244-271, https://doi.org/10.1016/j.cej.2015.01.135.

44. Nuraqeelah, M.S.; Wee, B.S.; Chin, S.F.; Kok, K.Y. Synthesis and characterization of zinc oxide nanoparticles with small particle size distribution. Acta Chimica Slovenica 2018, 65, 578-585, https://doi.org/10.17344/acsi.2018.4213.

45. Zhou, M.; Wei, Z.; Qiao, H.; Zhu, L.; Yang, H.; Xia, T. Particle size and pore structure characterization of silver nanoparticles prepared by confined arc plasma. J. Nanomater. 2009, 2009, 1-5. https://doi.org/10.1155/2009/968058.

46. Droepenu, E.K.; Asare, E.A. Morphology of green synthesized ZnO nanoparticles using low temperature hydrothermal technique from aqueous Carica papaya extract. Nanoscience and Nanotechnology 2019, 9, 2936.

47. Droepenu, E.K.; Boon, S.W.; Chin, S.F.; Kuan, Y.K.; Zaini, B.A.; Asare, E.A. Comparative evaluation of antibacterial efficacy of biological synthesis of $\mathrm{ZnO}$ nanoparticles using fresh leaf extract and fresh stem bark of carica papaya. Nano Biomed. Eng. 2019, 11, 264-271, https://doi.org/10.5101/nbe.v11i3.p264-271.

48. Bai, X.; Li, L.; Liu, H.; Tan, L.; Liu, T.; Meng, X. Solvothermal synthesis of ZnO nanoparticles and antiinfection application in vivo. ACS Applied Materials \& Interface 2015, 7, 1308-1317, https://doi.org/10.1021/am507532p.

49. Wang, Y.X.; Sun, J.; Yu, X.A. CTAB hydrothermal and solvothermal synthesis of ZnO nanopowders. Ceramics International 2011, 37, 3431-3436, https://doi.org/10.1016/j.ceramint.2011.04.134.

50. Cullity, B.D. Elements of X-ray Diffractions. Addison Wesley Publishing 1957.

51. Sangkhaprom, N.; Supaphol, P.; Pavarajarn, V. Fibrous zinc oxide prepared by combined electrospinning and solvothermal techniques. Ceramics International 2010, 36, 357-360, https://doi.org/10.1016/j.ceramint.2009.09.014.

52. Wojnarowicz, J.; Opalinska, A.; Chudoba, T.; Gierlotka, S.; Mukhovskyi, R.; Pietrzykowska, E.; Sobczak, K.; Lojkowski, W. Effect of Water Content in Ethylene Glycol Solvent on the Size of ZnO Nanoparticles Prepared Using Microwave Solvothermal Synthesis. Journal of Nanomaterials 2016, 2016, 1-15, https://doi.org/10.1155/2016/2789871.

53. Al Othman, Z.A.; Hashem, A.; Habila, M.A. Kinetic, Equilibrium and Thermodynamic Studies of Cadmium (II) Adsorption by Modified Agricultural Wastes. Molecules 2011, 16, 10443-10456; https://doi.org/10.3390/molecules161210443. 
54. Borhan, A.; Abdullah, N.A.; Rashidi, N.A.; Taha, M.F. Removal of $\mathrm{Cu}^{2+}$ and $\mathrm{Zn}^{2+}$ from single metal aqueous solution using rubber-seed shell based activated carbon. Proced. Eng. 2016, 148, 694-701, https://doi.org/10.1016/j.proeng.2016.06.571.

55. Sun, K.; Jiang, J.C. Preparation and characterization of activated carbon from rubber-seed shell by physical activation with steam. Biomass. Bioenerg. 2010, 34, 539-544, https://doi.org/10.1016/j.biombioe.2009.12.020.

56. Khoshhesab, Z.M.; Sarfaraz, M.; Asadabad, M.A. Preparation of ZnO Nanostructures by Chemical Precipitation Method. Synthesis and Reactivity in Inorganic, Metal-Organic, and Nano-Metal Chemistry 2011, 41, 814-819, https://doi.org/10.1080/15533174.2011.591308.

57. Peres, M.L.; Delucis, R.A.; Amico, S.C.; Gatto, D.A. Zinc oxide nanoparticles from microwave-assisted solvothermal process: Photocatalytic performance and use for wood protection against xylophagous fungus. Nanomaterials and Nanotechnology 2019, 9, 1-8, https://doi.org/10.1177/1847980419876201.

58. Joshi, S.; Pokharel, B.P. Preparation and characterization of activated carbon from Lapsi (Choerospondias axillaris) seed stone by chemical activation with potassium hydroxide. J. Inst. Eng. 2013, 9, 79-88, https://doi.org/10.3126/jie.v9i1.10673.

59. Pathania, D.; Sharma, S.; Singh, P. Removal of MB by adsorption onto activated carbon developed from Ficus carica bast. Arab. J. Chem. 2017, 10, 1445-1451, https://doi.org/10.1016/j.arabjc.2013.04.021.

60. Moniruzzaman, M.; Rahman, M.A.; Aktar, S.; Khan, M. Equilibrium and Kinetic Parameters Determination of $\mathrm{Cr}(\mathrm{VI})$ Adsorption by Hogla Leaves (Typha elephantina Roxb). Int. J. Waste. Resour. 2017, 7, 1-7, https://doi.org/10.4172/2252-5211.1000301.

61. Singha, B.; Das, S.K. Bisorption of Cr (VI) ions from aqueous solution: kinetics, equilibrium and thermodynamicsand desorption studies. Colloids and Surfaces B: Biointerface 2011, 84, 221-232, https://doi.org/10.1016/j.colsurfb.2011.01.004.

62. Tan, C.H.C.; Sabar, S.; Hussin, M.H. Development of immobilized microcrystalline cellulose as an effective adsorbent for methylene blue dye removal. S. Afr. J. Chem. Eng. 2018, 26, 11-24, https://doi.org/10.1016/j.sajce.2018.08.001.

63. Aydin, H.; Bulut, Y.; Yerlikaya, C. Removal of copper (II) from aqueous solution by adsorption onto lowcost adsorbents. J. Environmental Management $2008, \quad 87, \quad 37-45$, https://doi.org/10.1016/j.jenvman.2007.01.005.

64. Akar, S.T.; Ozcan, A.S.; Akar, T.; Ozcan, A.; Kaynak, Z. Biosorption of a reactive textile dye from aqueous solutions utilizing an agrowaste. Desalination 2009, 249, 757-761, https://doi.org/10.1016/j.desal.2008.09.012.

65. Bhatti, H.N.; Mumtaz, B.; Muhammad, A.H.; Nadeem, R. Removal of Zn (II) ions from aqueous solution using Moringa oleifera Lam (Horseradish Tree) biomass. Process Biochemistry 2007, 42, 547-553, https://doi.org/10.1016/j.procbio.2006.10.009.

66. Putra, W.P.; Kamari, A.; Yusoff, S.N.M.; Ishak, C.F.; Mohamed, A.; Hashim, N.; Isa, I.Md. Biosorption of $\mathrm{Cu}(\mathrm{II}), \mathrm{Pb}(\mathrm{II})$ and $\mathrm{Zn}$ (II) ions from aqueous solutions using selected waste materials: Adsorption and characterisation studies. J. Encapsul. Adsorp. Sci. 2014, 4, 25-35. https://doi.org/10.4236/jeas.2014.41004.

67. Reddy, D.; Seshaiah, K.; Reddy, A.V.R.; Lee, S.M. Optimization of Cd(II), Cu(II) and Ni(II) biosorption by chemically modified Moringa oleifera leaves powder. Carbohydr. Polym 2010, 88, 1077-1086, https://doi.org/10.1016/j.carbpol.2012.01.073.

68. Parvin, S.; Biswas, B.K.; Rahman, M.A.; Rahman, M.H.; Anik, M.S.; Uddin, M.R. Study on adsorption of Congo red onto chemically modified egg shell membrane. Chemosphere 2019, 236, https://doi.org/10.1016/j.chemosphere.2019.07.057.

69. Lakherwal, D.; Rattan, V.K.; Singh, H.P. Studies on adsorption of nickel by activated carbon in a liquid fluidised bed reactor. Canadian. Chem. Trans. 2016, 4, 121-132, https://doi.org/10.13179/canchemtrans.2016.04.01.0264.

70. Agbozu, I.E.; Emoruwa, F.O. Batch adsorption of heavy metals $(\mathrm{Cu}, \mathrm{Pb}, \mathrm{Fe}, \mathrm{Cr}$ and $\mathrm{Cd})$ from aqueous solutions using coconut husk. African Journal of Environmental Science and Technology 2014, 8, 239-246, https://doi.org/10.5897/AJEST2013.1577.

71. Roulia, M.; Vassiliadis, A.A. Sorption characterization of a cationic dye retained by clays and perlite. Microporous Mesoporous Materials 2008, 116, https://doi.org/10.1016/j.micromeso.2008.03.017.

72. Desta, M.B. Batch adsorption experiments: Langmuir and Freundlich isotherm studies for the adsorption of textile metal ions onto Teff straw (Eragrostis tef) agricultural waste. J. Thermodyn. 2013, 2013, 1-6, https://doi.org/10.1155/2013/375830.

73. Gao, Y.; Li, Y.; Zhang, L.; Huang, H.; Hu, J.; Shah, S.M.; Su, X. Adsorption and removal of tetracycline antibiotics from aqueous solution by graphene oxide. J. Colloid Interface Sci. 2012, 368, 540-546, https://doi.org/10.1016/j.jcis.2011.11.015.

74. Lafi, R.; Hafiane, A. Removal of methyl orange (MO) from aqueous solution using cationic surfactants modified coffee waste (MCWs). J. Taiwan Inst. Chem. Eng. 2016, 58, 424-433, https://doi.org/10.1016/j.jtice.2015.06.035. 
75. Vijayakumar, G.; Tamilarasan, R.; Dharmendirakumar, M. Adsorption, Kinetic, Equilibrium and Thermodynamic studies on the removal of basic dye Rhodamine-B from aqueous solution by the use of natural adsorbent perlite. J. Mater. Environ. Sci. 2012, 3,157-170. 